\title{
Overview of the Mount Tai Experiment (MTX2006) in central East China in June 2006: studies of significant regional air pollution
}

\author{
Y. Kanaya ${ }^{1}$, H. Akimoto ${ }^{1, *}$, Z.-F. Wang ${ }^{2}$, P. Pochanart ${ }^{1,{ }^{* *}}$, K. Kawamura ${ }^{3}$, Y. Liu ${ }^{1,2}$, J. Li $^{1,2}$, Y. Komazaki ${ }^{1}$, \\ H. Irie ${ }^{1, * * *}$, X.-L. Pan ${ }^{1}$, F. Taketani ${ }^{1}$, K. Yamaji ${ }^{1, * * * *}$, H. Tanimoto ${ }^{4}$, S. Inomata ${ }^{4}$, S. Kato ${ }^{5}$, J. Suthawaree ${ }^{5}$, \\ K. Okuzawa ${ }^{3}$, G. Wang ${ }^{3, * * *}$, S. G. Aggarwal ${ }^{3, * * * * * *}$, P. Q. Fu ${ }^{3,2}$, T. Wang ${ }^{6}$, J. Gao ${ }^{6}$, Y. Wang ${ }^{2}$, and G. Zhuang ${ }^{7}$ \\ ${ }^{1}$ Research Institute for Global Change, Japan Agency for Marine-Earth Science and Technology, 3173-25 Showa-machi, \\ Kanazawa-ku, Yokohama 2360001, Japan \\ ${ }^{2}$ LAPC, Institute for Atmospheric Physics, Chinese Academy of Sciences, Beijing 100029, China \\ ${ }^{3}$ Institute of Low Temperature Science, Hokkaido University, Sapporo 0600819, Japan \\ ${ }^{4}$ National Institute for Environmental Studies, Tsukuba 3058506, Japan \\ ${ }^{5}$ Tokyo Metropolitan University, Hachioji 1920397, Japan \\ ${ }^{6}$ The Hong Kong Polytechnic University, Hong Kong, China \\ ${ }^{7}$ Fudan University, Shanghai 200433, China \\ * now at Asia Center for Air Pollution Research, Niigata 9502144, Japan \\ ** now at: National Institute of Development Administration, Bangkok 10240, Thailand \\ *** now at: Chiba University, Chiba 2638522, Japan \\ **** now at: Kobe University, Kobe 6580022, Japan \\ ***** now at: Institute of Earth Environment, Chinese Academy of Sciences, Xi' an 710075, China \\ ******* now at: National Physical Laboratory, New Delhi 110012, India
}

Correspondence to: Y. Kanaya (yugo@jamstec.go.jp)

Received: 25 December 2012 - Published in Atmos. Chem. Phys. Discuss.: 15 January 2013

Revised: 11 May 2013 - Accepted: 13 May 2013 - Published: 22 August 2013

\begin{abstract}
We conducted an intensive field campaign at the summit of Mt. Tai $\left(36.26^{\circ} \mathrm{N}, 117.11^{\circ} \mathrm{E}, 1534 \mathrm{~m}\right.$ above sea level), Shandong Province, located at the center of central East China, during the period 28 May to 30 June 2006, to study seasonal maxima of regional air pollution with respect to ozone $\left(\mathrm{O}_{3}\right)$ and aerosols. The specific objectives, campaign design, and major findings are summarized. High concentrations of $\mathrm{O}_{3}$ and its precursors, and aerosols, were detected and studied in the context of annual variations. Most importantly, we identified that emissions from regionalscale open crop residue burning after the harvesting of winter wheat, together with photochemical aging, strongly increased the concentrations of $\mathrm{O}_{3}$, aerosols, and primary pollutants in this month of year. Studies of in situ photochemical activity, regional source attribution of $\mathrm{O}_{3}, \mathrm{O}_{3}$-aerosol interactions, validation of satellite observations of tropospheric $\mathrm{NO}_{2}$, behaviors of volatile organic compounds and organic/inorganic aerosol species, loss rates of black car-
\end{abstract}

bon (BC), and instrument inter-comparisons are also summarized. The observed BC levels must have a strong impact on the regional climate.

\section{Introduction}

Asian regional air pollution is a major element of global air pollution (Akimoto, 2003) and is of great interest from the viewpoints of urban and rural air quality, trans-boundary air pollution, hemispherical air pollution, and climate impacts. Central East China (CEC), covering the North China Plain (NCP) and the Yangtze River delta region, stands out as the most highly polluted area in this region, as evidenced by satellite observations of $\mathrm{NO}_{2}$, which is regarded as representative of air pollutants (Beirle et al., 2004; Martin et al., 2006), and aerosols (Chin et al., 2004). It has also been observed that the tropospheric column density of 
$\mathrm{NO}_{2}$ has been increasing rapidly since 2000 (Richter et al., 2005). Measurements of the aerosol optical depth (AOD) at $550 \mathrm{~nm}$, performed by the satellite sensors MODIS/Terra and MODIS/Aqua from 2000, suggest that the NCP has one of the highest AOD values. The observed AOD has seasonal variations, with a maximum $(\sim 1.0)$ in June-July and a minimum $(\sim 0.5)$ in November-January. In contrast to satellite remote-sensing data, however, ground-based in situ observational data (except in urban or near-urban areas) are very scarce, and information on the actual circumstances of regional air pollution, particularly for ozone $\left(\mathrm{O}_{3}\right)$, aerosols, and their precursors, has not been available for this region.

Among the regional air pollutants in $\mathrm{CEC}, \mathrm{O}_{3}$ and black carbon (BC) are of particular importance in the context of global climate change, since they are short-lived climate forcers with positive radiative forcing (RF), and are thought to contribute as much as long-lived greenhouse gases do to global warming (IPCC, 2007). High concentrations of $\mathrm{O}_{3}$ are very toxic to humans (WHO, 2003) as well as to natural ecosystem and agricultural crops (Fuhrer et al., 1997; USEPA, 2006). In this context, to obtain in situ observational data of air pollutants such as $\mathrm{O}_{3}, \mathrm{BC}$, other aerosol components, and their precursors, the Frontier Research Center for Global Change (FRCGC) of the Japan Agency for MarineEarth Science and Technology (JAMSTEC), and the Institute of Atmospheric Physics (IAP), Chinese Academy of Sciences (CAS), organized a field campaign named MTX2006 (Mount Tai Experiment 2006) at the summit of Mt. Tai $\left(36.26^{\circ} \mathrm{N}, 117.11^{\circ} \mathrm{E}, 1534 \mathrm{~m}\right.$ a.s.l.) in Shandong Province, China, in June 2006. Mt. Tai is located at the center of the $\mathrm{NCP}$, and is expected to provide regionally representative data for CEC. The obtained data and their analysis are presented in this special issue.

Prior to the MTX2006 campaign, we identified seasonal variations in surface $\mathrm{O}_{3}$ at three mountain sites in CEC: at Mt. Tai, Mt. Hua $\left(34.48^{\circ} \mathrm{N}, 110.08^{\circ} \mathrm{E}, 2065 \mathrm{~m}\right.$ a.s.l., Shaanxi Province), and Mt. Huang $\left(30.16^{\circ} \mathrm{N}, 118.26^{\circ} \mathrm{E}\right.$, 1840 m a.s.l., Anhui Province), as shown in Fig. 1. From the results, we found that the $\mathrm{O}_{3}$ concentration was highest at Mt. Tai, with a monthly peak in June, followed by Mt. Hua and Mt. Huang, for which the peaks were smaller and appeared earlier, i.e., in late spring ( $\mathrm{Li}$ et al., 2007). The highest concentration of $\mathrm{O}_{3}$ at Mt. Tai was in accord with the spatial distribution of emissions of $\mathrm{O}_{3}$ precursors, $\mathrm{NO}_{\mathrm{x}}$, and volatile organic compounds (VOCs), obtained in the emission inventory database (Ohara et al., 2007). The data show that Mt. Tai is in the middle of the highest emission area, Mt. Hua is at the western edge, and Mt. Huang is just outside the heavy emission area. We therefore selected Mt. Tai as our campaign site and chose June as the study period, to represent the most serious regional air pollution in CEC.

Z. Wang et al. (2006) simulated a regional high- $\mathrm{O}_{3}$ episode observed at two mountain sites (Mt. Tai and Mt. Huang) in May 2004, using the nested air quality prediction modeling system (NAQPMS), and found that it was the transport of
$\mathrm{O}_{3}$ and its precursors from the Yangtze Delta that caused the high- $\mathrm{O}_{3}$ episode at the two sites, with contributions of 20 $50 \%$ during the episode. However, the lack of measurements of $\mathrm{O}_{3}$ precursors prevented detailed studies.

Gao et al. (2005) reported $\mathrm{O}_{3}$ and $\mathrm{CO}$ observations at the summit of Mt. Tai during the period June-November 2003 , showing average concentrations of $58 \pm 16 \mathrm{ppbv}$ for $\mathrm{O}_{3}$ and $393 \pm 223 \mathrm{ppbv}$ for $\mathrm{CO}$ during the study period. Another paper reported precipitation chemistry at Mt. Tai (Wang et al., 2008b). Observations at Shangdianzi (a rural site in northern CEC) showed that the average maximum hourly $\mathrm{O}_{3}$ concentration in June exceeded $120 \mathrm{ppbv}$ (Lin et al., 2008). Xu et al. (2008) summarized surface $\mathrm{O}_{3}$ data from the Lin'an regional background station, Zhejiang Province, in the Yangtze Delta region, during six periods between August 1991 and July 2006 (Luo et al., 2000; Wang et al., 2001, 2004). The seasonal cycle shows two peaks at around $40-50 \mathrm{ppbv}$, with the primary peak in May and the secondary peak in October. A maximum hourly mean $\mathrm{O}_{3}$ concentration of $156 \mathrm{ppbv}$ occurred in June 2006. Intensive field campaigns including measurements of $\mathrm{O}_{3}, \mathrm{CO}, \mathrm{NO}_{\mathrm{y}}$, $\mathrm{SO}_{2}$, and VOCs were performed at Lin'an, in 1999-2000 and in spring 2001 (Wang et al., 2002, 2004) and key emission factors (e.g., $\mathrm{CO} / \mathrm{NO}_{\mathrm{x}}$ ) were studied. They observed the highest $\mathrm{CO} / \mathrm{NO}_{\mathrm{y}}$ ratios $\left(30-40 \mathrm{ppbv}_{\mathrm{ppbv}}{ }^{-1}\right)$ in SeptemberDecember 1999 and June 2000. Based on the good correlation between $\mathrm{CO}$ and a biomass burning tracer in fall, they suggested that the burning of biofuels and/or crop residues was a major source for the elevated $\mathrm{CO}$ observed at their site (Wang et al., 2002).

To our knowledge, there have been no other papers reporting measurements of $\mathrm{O}_{3}$ and its precursors in 2006 or earlier at regionally representative sites in the NCP that can be used for comparisons with results from regional or global chemical transport models. MTX2006 is therefore the first intensive campaign to provide a comprehensive set of near-surface air pollutant concentrations at a regionally representative site in the NCP.

The MTX2006 study is a component of the $\mathrm{O}_{3}$ and BC project sponsored by the Global Environmental Research Fund of the Ministry of the Environment, Japan. This paper presents an overview of the campaign and the obtained results, and a synthesis of the individual papers presented in this special issue on MTX2006, encompassing from field observations to modeling, remote sensing, and laboratory studies. Also, we newly explore comparisons of $\Delta \mathrm{CO} / \Delta \mathrm{NO}_{\mathrm{y}}$, $\Delta \mathrm{O}_{3} / \Delta \mathrm{NO}_{\mathrm{z}}$, and $\mathrm{NO} / \mathrm{NO}_{2}$ ratios between observations and model simulations (in Sects. 6.1 and 6.4), correlations between VOCs and levoglucosan (in Sect. 6.6), dependence of OC mass concentrations on air mass age (in Sect. 6.9), and fractions of $\mathrm{OC}$ that were molecularly identified (in Sect. 6.9). 

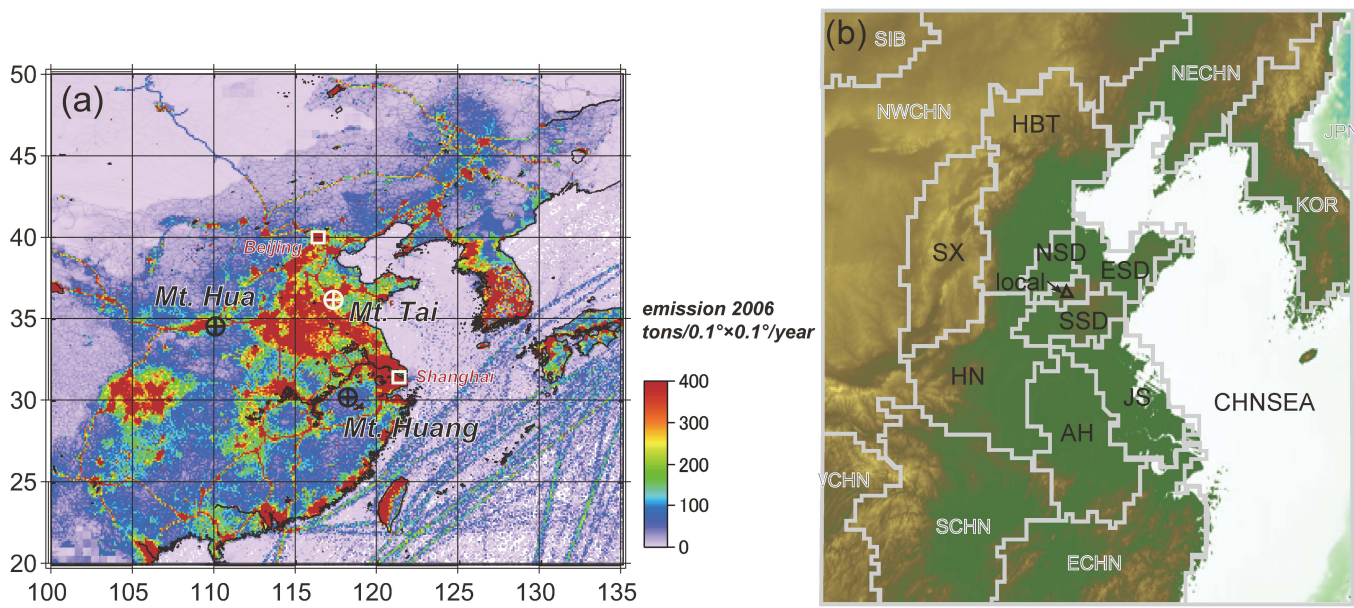

Fig. 1. (a) Geographical locations of Mt. Tai, Mt. Hua and Mt. Huang superimposed on EDGAR v.4.2 emission inventory map of NO (2006). (b) Terrain of CEC and the major source regions used in the NAQPMS model simulations (see Sect. 6.3 for more details). Location of Mt. Tai is indicated by a triangle.

\section{Specific objectives of MTX2006}

The general objective of MTX2006 was to quantify $\mathrm{O}_{3}$, aerosols (including $\mathrm{BC}$ ), and their precursors in the middle of the NCP. To attain this objective, the specific aims were to answer the following questions.

1. What are the concentrations of surface $\mathrm{O}_{3}$, aerosols (including $\mathrm{BC}$ ), their precursors, and related species at the top of Mt. Tai, located in the middle of the regional pollution area of CEC, in the highest pollution season of June?

2. Why does the surface $\mathrm{O}_{3}$ concentration peak sharply in June, as opposed to showing a broad plateau in the summer as observed in Europe, another continental source region?

3. How much of the $\mathrm{O}_{3}$ is transported to Mt. Tai from other regions, and how much is produced locally?

4. How fast is the in situ photochemical production of $\mathrm{O}_{3}$ at Mt. Tai? Is the $\mathrm{O}_{3}$ production regime $\mathrm{NO}_{\mathrm{x}}$ limited or VOC limited?

5. What are the characteristics of the VOC composition compared with those of other urban/rural areas?

6. How well do the BC concentrations measured using different techniques agree with each other?

7. What is the major constituent of the aerosol particles? Are secondary organic aerosols and oxygenated VOCs (OVOCs) such as $\mathrm{HCHO}$ present abundantly, as inferred from the high $\mathrm{O}_{3}$ levels?
8. How reliable are the satellite observations of $\mathrm{NO}_{2}$ in CEC? Do they agree with MAX-DOAS (multi-axisdifferential optical absorption spectroscopy) observations?

9. What are the effects of aerosols on spectral actinic fluxes and $J$ values (photolysis frequencies) of several atmospheric molecules relevant to photochemistry?

10. Can we identify sources of OC (organic carbon) aerosol particles using levoglucosan as a biomass and biofuel tracer, lignin products as tracers for pine trees, and hopanoid hydrocarbons as automobile tracers? What are their temporal variations? What is the fraction of OC that we can identify molecularly?

During early June, we easily recognized that the atmospheric composition at the field site was strongly influenced by largescale post-harvest open crop residue burning (OCRB, winter wheat). As a result, a large number of the papers in this issue are devoted to studies of the impact of open biomass burning on $\mathrm{O}_{3}$, its precursors, and aerosol compositions, although this was not specifically targeted in the planning stage.

\section{Geography of Mt. Tai}

The campaign site is the meteorological observatory at the summit of Mt. Tai $\left(36.26^{\circ} \mathrm{N}, 117.11^{\circ} \mathrm{E}, 1534 \mathrm{~m}\right.$ a.s.l. $)$, which is located in the Shandong Province in the NCP in CEC. Figure 1a shows the location of Mt. Tai, superimposed on the emission inventory map of $\mathrm{NO}_{2}$ (EDGAR v.4.2, source: EC-JRC/PBL EDGAR version 4.2, http://edgar.jrc. ec.europa.eu/, 2011) for the year 2006, showing that the campaign site is located in the middle of a high $\mathrm{NO}_{2}$ emission area of CEC. Shandong Province is mostly flat in terrain (Fig. 1b); only its central part is relatively hilly, and 
Table 1. Observed species and methods, and investigators responsible for observations.

\begin{tabular}{|c|c|c|}
\hline Observed species & Method & Investigator, Affiliation \\
\hline $\mathrm{O}_{3}, \mathrm{CO}$ & UV absorption, NDIR & P. Pochanart, JAMSTEC \\
\hline $\mathrm{O}_{3}$ & UV absorption & T. Wang, J. Gao, Shandong Univ. \\
\hline $\mathrm{NO} / \mathrm{NO}_{\mathrm{x}} / \mathrm{NO}_{\mathrm{y}}$ & $\begin{array}{l}\text { LED/Molybdenum converter/ } \\
\text { Chemiluminescence }\end{array}$ & H. Tanimoto, NIES \\
\hline NMHCs & Canister/GC-FID/GC-MS & S. Kato, Tokyo Metropolitan Univ. \\
\hline $\mathrm{NMHCs}$ & Canister/GC-MS & Y. Wang, IAP \\
\hline NMHCs, VOCs & PTR-MS & H. Tanimoto, S. Inomata, NIES \\
\hline $\mathrm{CO}_{2}$ & NDIR & Y. Komazaki, JAMSTEC \\
\hline $\mathrm{NO}_{2} \mathrm{VCD} \& \mathrm{AOD}$ from mountain & MAX-DOAS & H. Irie, Y. Kanaya, JAMSTEC \\
\hline $\mathrm{NO}_{2} \mathrm{VCD} \& \mathrm{AOD}$ from foothill & MAX-DOAS & H. Irie, Y. Kanaya, JAMSTEC \\
\hline Actinic flux \& $J$ values & Spectral radiometry & Y. Kanaya, JAMSTEC \\
\hline$T, \mathrm{RH}, P$, wind & Conventional instruments & Meteorological observatories \\
\hline Black carbon $\left(\mathrm{PM}_{1}, \mathrm{PM}_{2.5}\right)$ & Multi-angle absorption photometry & P. Pochanart, JAMSTEC \\
\hline $\mathrm{EC} / \mathrm{OC}$ & Thermal-optical-transmittance & Y. Komazaki, JAMSTEC \\
\hline Black carbon & Particle soot absorption photometry & Y. Komazaki, JAMSTEC \\
\hline Black carbon & Aethalometer & T. Wang, J. Gao, Shandong Univ. \\
\hline Ions and metals of size segregated aerosol particles & Cascade impactor/post analysis & Y. Wang, IAP \\
\hline Ions and metals of TSP and $\mathrm{PM}_{2.5}$ & Sampling/post analysis & G. Zhuang, Fudan Univ. \\
\hline Organic gases/aerosols & $\begin{array}{l}\text { High volume air sampler, filter } \\
\text { pack collections/post analysis }\end{array}$ & K. Kawamura, Hokkaido Univ. \\
\hline PAHs/size segregated aerosols & Sampling/ post analysis & G. Wang, Nanjing/Hokkaido Univ. \\
\hline
\end{tabular}

Mt. Tai is the highest and isolated peak located in a UNESCO (United Nations Educational, Scientific, and Cultural Organization) World Heritage site. Although there are several small restaurants, shops, temples, and hotels for tourists $\sim 500 \mathrm{~m}$ away in the mountain top area, emissions from these sources are thought to be too small to affect the observational data. Mt. Tai is about $6 \mathrm{~km}$ north of the city of Tai' an (population in its central region: ca. 1.5 million) and is about $60 \mathrm{~km}$ southeast of the provincial capital city, Jinan (population: ca. 4.3 million). So, although the air mass at the top of Mt. Tai would be affected by regional emissions when the boundary layer builds up, covering the top of the mountains in the afternoon, as will be described later, the site is believed to be free from local anthropogenic pollution, and is expected to provide regionally representative data.

\section{Measured species, campaign period, and meteorological conditions}

Table 1 lists the measured species and parameters along with methods, responsible investigator(s) and affiliation. Detailed descriptions of each instrument are included in companion papers of this special issue. They included $\mathrm{O}_{3}, \mathrm{NO}_{\mathrm{x}} / \mathrm{NO}_{\mathrm{y}}$, NMHC (non-methane hydrocarbons), VOCs, CO and spectral actinic flux (see Kanaya et al., 2009; Suthawaree et al., 2010; Inomata et al., 2010), and composition of aerosols including BC/EC (elemental carbon) and OC mass concentrations (Kanaya et al., 2008), molecular composition of organic aerosols (Wang et al., 2009; Fu et al., 2008, 2010, 2012;
Kawamura et al., 2013a, b), and ionic composition (Deng et al., 2011; Xu et al., 2009). $\mathrm{CO}_{2}$ measurements (LI-840, LICOR biosciences, Lincoln, NE, USA) were made to assist discussion on sources of aerosols and gases. Conventional meteorological parameters were also obtained. In addition to in situ measurements, remote sensing measurements of $\mathrm{NO}_{2}$ vertical column density (VCD) and AOD were made by MAX-DOAS instruments located both at the top and foothill of the mountain (Irie et al., 2008). The foothill site is located at $36.16^{\circ} \mathrm{N}, 117.15^{\circ} \mathrm{E}, 126 \mathrm{~m}$ a.s.l.

In addition to the main organizing institutes, namely FRCGC/JAMSTEC and IAP/CAS, scientists from several other universities and research institutes participated in the campaign. As seen from Table 1, these included the National Institute for Environmental Studies (NIES), Tokyo Metropolitan University, and Hokkaido University in Japan; and Shandong University, Fudan University, and Nanjing University in China.

The MTX2006 campaign was conducted during the period from 28 May to 30 June 2006. The actual measurement period depends on the instrument. The meteorological conditions are summarized in Fig. 2. On 9, 15, and 29 June, lowpressure systems passed over the region. During the periods of passage, the wind direction was north. During the period 22-25 June, the main wind direction was east, as a result of a high-pressure system located in the east, near Japan. The wind direction in the other periods was normally south or southwest. Precipitation was recorded on 7, 13, 14, 21, 22, 26,28 , and 29 June. The average daytime maxima of $J\left(\mathrm{NO}_{2}\right)$ and $J\left(\mathrm{O}^{1} \mathrm{D}\right)(2 \pi \mathrm{sr})$ were $7.4 \times 10^{-3}$ and $2.8 \times 10^{-5} \mathrm{~s}^{-1}$, 


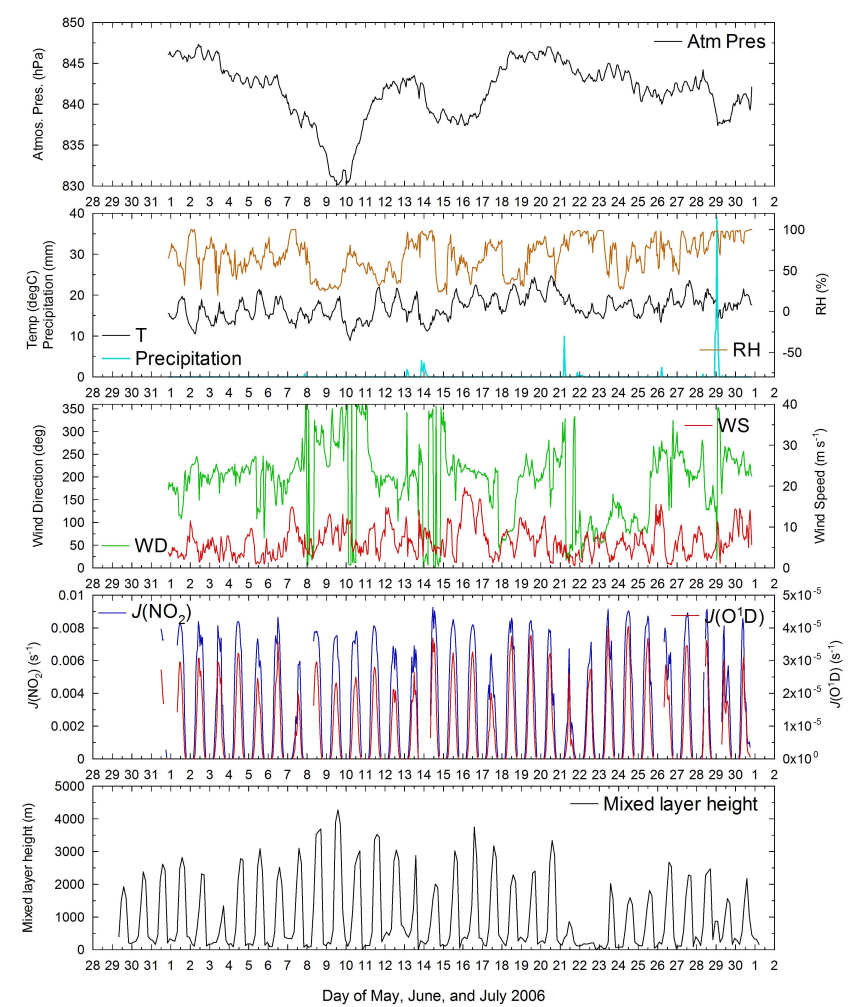

Fig. 2. Time series of atmospheric pressure, temperature, RH, precipitation, wind direction and speed, $J\left(\mathrm{NO}_{2}\right)$, and $J\left(\mathrm{O}^{1} D\right)$ values, and mixed layer height.

respectively. The temperature and relative humidity (RH) ranges were $9-25^{\circ} \mathrm{C}$ and $20-100 \%$, with averages of $17^{\circ} \mathrm{C}$ and $67 \%$, respectively. The mixed layer height (GDAS1, Air Resources Laboratory, NOAA) was about $240 \mathrm{~m}$ during night and reached maxima (around $2500 \mathrm{~m}$ ) at 14:00 LT (LT $=\mathrm{UTC}+8 \mathrm{~h}$ ). The observation site was typically within the planetary boundary layer during daytime and within the residual layer during nighttime.

\section{Modeling activities}

Modeling activities were included as part of MTX2006 as post-mission analysis. Table 2 lists the modeling systems used, targeted subjects, and principal investigator and affiliation. A one-box model was used to study photochemical production and loss of $\mathrm{O}_{3}$ by fixing the key species and parameters to observed values (Kanaya et al., 2009). Two different three-dimensional chemical transport models (3-D CTM) were used; one is NAQPMS, developed by Z. Wang et al. (2006), and the other is Community Multiscale Air Quality Modeling System (CMAQ), developed by Byun and Ching (1999). The NAQPMS was used for studying source attribution and outflow of $\mathrm{O}_{3}$ at Mt. Tai (Li et al., 2008a). The CMAQ was used to evaluate the impact of crop residue burning on $\mathrm{O}_{3}, \mathrm{CO}, \mathrm{BC}$, and $\mathrm{OC}$ over CEC (Yamaji et al., 2010), and to study the impact of the Asian monsoon on $\mathrm{O}_{3}$ and precipitation acidity in eastern and central China (He et al., 2008; Ge et al., 2011).

\section{Overview of MTX2006 findings}

In this section, our findings with MTX2006 are sorted by topics and overviewed. First, in Sect. 6.1, after showing overall time series of major species, we compare their concentration levels, their ratios (e.g., $\Delta \mathrm{CO} / \Delta \mathrm{NO}_{\mathrm{y}}$ ), and air mass ages with those reported for past regional and urban studies, to highlight chemical conditions and their features during the MTX2006 field campaign. Then, key findings from companion papers are given in an integrated manner in Sects. 6.26.9. Moreover, in Sects. 6.4, 6.6, and 6.9, we added original analyses with respect to $\Delta \mathrm{CO} / \Delta \mathrm{NO}_{\mathrm{y}}, \Delta \mathrm{O}_{3} / \Delta \mathrm{NO}_{\mathrm{z}}$, and $\mathrm{NO} / \mathrm{NO}_{2}$ ratios, correlations between VOCs and levoglucosan, dependence of OC mass concentrations on air mass age, and fractions of OC that were molecularly identified.

\subsection{High concentrations of $\mathrm{O}_{3}$ and aerosols at Mt. Tai, and related features}

Figure 3 shows the overall temporal variations in $\mathrm{O}_{3}, \mathrm{CO}$, benzene, $\mathrm{CO}_{2}, \mathrm{NO}_{\mathrm{x}}, \mathrm{NO}_{\mathrm{y}}, \mathrm{BC}, \mathrm{OC}$, sulfate, and nitrate concentrations during the campaign period. For individual species, see Suthawaree et al. (2010) for benzene, Kanaya et al. (2009) for other gas species, Kanaya et al. (2008) for carbonaceous aerosols, and Deng et al. (2011) for watersoluble ions for more details. Table 3 lists their average, maximum, and minimum concentrations. In Fig. 3, two highconcentration episodes are clearly seen for most gases and aerosols during the periods 6-7 and 12-13 June. These episodes are caused by the strong impact of OCRB, as will be discussed later. A regular diurnal pattern with a daytime maximum and nighttime minimum can be seen, particularly for $\mathrm{NO}_{\mathrm{y}}, \mathrm{BC}$, and $\mathrm{OC}$ in the latter half of the campaign period. This pattern is the result of a polluted air mass being transported to the mountain top during the daytime; this is associated with the buildup of the planetary boundary layer. During the night, on the other hand, the observed air mass is isolated from pollution sources. It should be noted that the nighttime observations were generally made within the residual layer, and only occasionally in the free troposphere, considering that the daytime boundary layer height often exceeded the altitude of the observation site (see Fig. 2).

Very high $\mathrm{O}_{3}$ concentrations, with an hourly maximum of $160 \mathrm{ppbv}$ and a monthly average of $82 \mathrm{ppbv}$, were observed at the top of Mt. Tai in June 2006 (Fig. 3, Table 3). There are not many reports in the literature of similarly high hourly concentrations of $\mathrm{O}_{3}$ detected by continuous observations in China, even if sites influenced by urban plumes are included. In the north outskirt region of Beijing, for example, 
Table 2. MTX2006 modeling activities.

\begin{tabular}{|c|c|c|c|c|}
\hline Model Type & Model Name & $\begin{array}{l}\text { Horizontal } \\
\text { Resolution }\end{array}$ & Research Subject & PI, Affiliation \\
\hline 0-D Box Model & RACM & NA & $\begin{array}{l}\text { Photochemical } \mathrm{O}_{3} \\
\text { production }\end{array}$ & Y. Kanaya, JAMSTEC \\
\hline 3-D CTM & NAQPMS/ MM5 & $\begin{array}{l}27 \times 27 \mathrm{~km} \text { nested } \\
\text { into } 81 \mathrm{~km} \text { grids }\end{array}$ & Source attribution of $\mathrm{O}_{3}$ & J. Li, JAMSTEC/ IAP \\
\hline 3-D CTM & CMAQ v.4.4/ RAMS v.4.4 & $80 \times 80 \mathrm{~km}$ & $\begin{array}{l}\text { Impact of crop residual } \\
\text { burning on air quality }\end{array}$ & K. Yamaji, JAMSTEC \\
\hline 3-D CTM & CMAQ v.4.4 & $\begin{array}{l}20 \times 20 \mathrm{~km} \text { nested } \\
\text { into } 80 \mathrm{~km} \text { grids }\end{array}$ & $\begin{array}{l}\text { Impact of Asian monsoon } \\
\text { on } \mathrm{O}_{3}\end{array}$ & Y. J. He, JAMSTEC \\
\hline 3-D CTM & CMAQ v.4.4/RAMS v.4.3 & $80 \times 80 \mathrm{~km}$ & $\begin{array}{l}\text { Impact of Asian monsoon } \\
\text { on acidity of precipitation }\end{array}$ & B.Z. Ge, IAP \\
\hline
\end{tabular}

Table 3. Average, maximum, and minimum concentrations of $\mathrm{O}_{3}$, $\mathrm{CO}, \mathrm{NO}_{\mathrm{x}}, \mathrm{NO}_{\mathrm{y}}, \mathrm{PM}_{2.5}, \mathrm{TSP}, \mathrm{BC}$ and $\mathrm{OC}$, sulfate, and nitrate at the summit of Mt. Tai in June 2006.

\begin{tabular}{llll}
\hline Species & Average & Maximum & Minimum \\
\hline $\mathrm{O}_{3}$ & $82 \mathrm{ppbv}$ & $160 \mathrm{ppbv}$ & $12 \mathrm{ppbv}$ \\
$\mathrm{CO}$ & $560 \mathrm{ppbv}$ & $1769 \mathrm{ppbv}$ & $90 \mathrm{ppbv}$ \\
$\mathrm{NO}_{\mathrm{x}}$ & $1.1 \mathrm{ppbv}$ & $8.8 \mathrm{ppbv}$ & $<\mathrm{DL}$ \\
$\mathrm{NO}_{\mathrm{y}}$ & $6.7 \mathrm{ppbv}$ & $21.6 \mathrm{ppbv}$ & $<\mathrm{DL}$ \\
$\mathrm{PM}_{2.5}$ & $123.1 \mu \mathrm{g} \mathrm{m}^{-3}$ & $235.7 \mu \mathrm{g} \mathrm{m}^{-3}$ & $48.0 \mu \mathrm{g} \mathrm{m}^{-3}$ \\
$\mathrm{TSP}$ & $135.0 \mu \mathrm{g} \mathrm{m}^{-3}$ & $276.9 \mu \mathrm{g} \mathrm{m}^{-3}$ & $49.2 \mu \mathrm{g} \mathrm{m}^{-3}$ \\
$\mathrm{BC}\left(\mathrm{PM}_{1}\right)$ & $3.4 \mu \mathrm{gC} \mathrm{m}^{-3}$ & $29.5 \mu \mathrm{gC} \mathrm{m}^{-3}$ & $<\mathrm{DL}$ \\
$\mathrm{OC}\left(\mathrm{PM}_{1}, \mathrm{NIOSH}\right)$ & $9.2 \mu \mathrm{gC} \mathrm{m}^{-3}$ & $76.7 \mu \mathrm{gC} \mathrm{m}^{-3}$ & $1.4 \mu \mathrm{gC} \mathrm{m}^{-3}$ \\
Sulfate $\left(\mathrm{PM}_{2.5}\right)$ & $21.0 \mu \mathrm{g} \mathrm{m}^{-3}$ & $45.1 \mu \mathrm{g} \mathrm{m}^{-3}$ & $4.0 \mu \mathrm{g} \mathrm{m}^{-3}$ \\
Nitrate $\left(\mathrm{PM}_{2.5}\right)$ & $8.5 \mu \mathrm{g} \mathrm{m}^{-3}$ & $21.6 \mu \mathrm{g} \mathrm{m}^{-3}$ & $1.8 \mu \mathrm{g} \mathrm{m}^{-3}$ \\
\hline
\end{tabular}

$<$ DL indicates below detection limit. $\mathrm{PM}_{2.5}$ and TSP: 2-30 June.

T. Wang et al. (2006) presented $\mathrm{O}_{3}$ data for a mountainous area (Changping) $50 \mathrm{~km}$ north of Beijing, for June-July 2005 with a monthly average of about $60 \mathrm{ppbv}$ and an hourly maximum record of 285 ppbv. Wang et al. (2008a) reported an hourly maximum of about $170 \mathrm{ppbv}$ with monthly averages of about $67 \mathrm{ppbv}$ at Miyun, a rural site $\sim 80 \mathrm{~km}$ northeast of Beijing, for June, July, and August 2006. The monthly maximum concentrations occurred in June, the same as at Mt. Tai. The monthly average $\mathrm{O}_{3}$ mixing ratio at Mt. Tai is therefore even higher than or similar to those at the two sites in the outskirts of Beijing. Ding et al. (2008) analyzed $\mathrm{O}_{3}$ profiles obtained over Beijing from 1995 to 2005 by the Measurement of Ozone and Water Vapor by Airbus In-Service Aircraft (MOZAIC) program. The maximum of $\mathrm{O}_{3}$ concentrations in the lower troposphere $(<2 \mathrm{~km})$ over Beijing was about $110 \mathrm{ppbv}$ in summer.

The monthly mean mixing ratio of $\mathrm{CO}$ at Mt. Tai, $560 \mathrm{ppbv}$ (Fig. 3, Table 3), is about the same as the $600 \mathrm{ppbv}$ and 600-700 ppbv levels reported at Miyun and Changping, respectively. The maximum level of $1769 \mathrm{ppbv}$ at Mt. Tai is also in a similar range to that in the outskirts of Beijing $(\sim 1500 \mathrm{ppbv})$. In contrast, the mixing ratios of $\mathrm{NO}_{\mathrm{y}}$

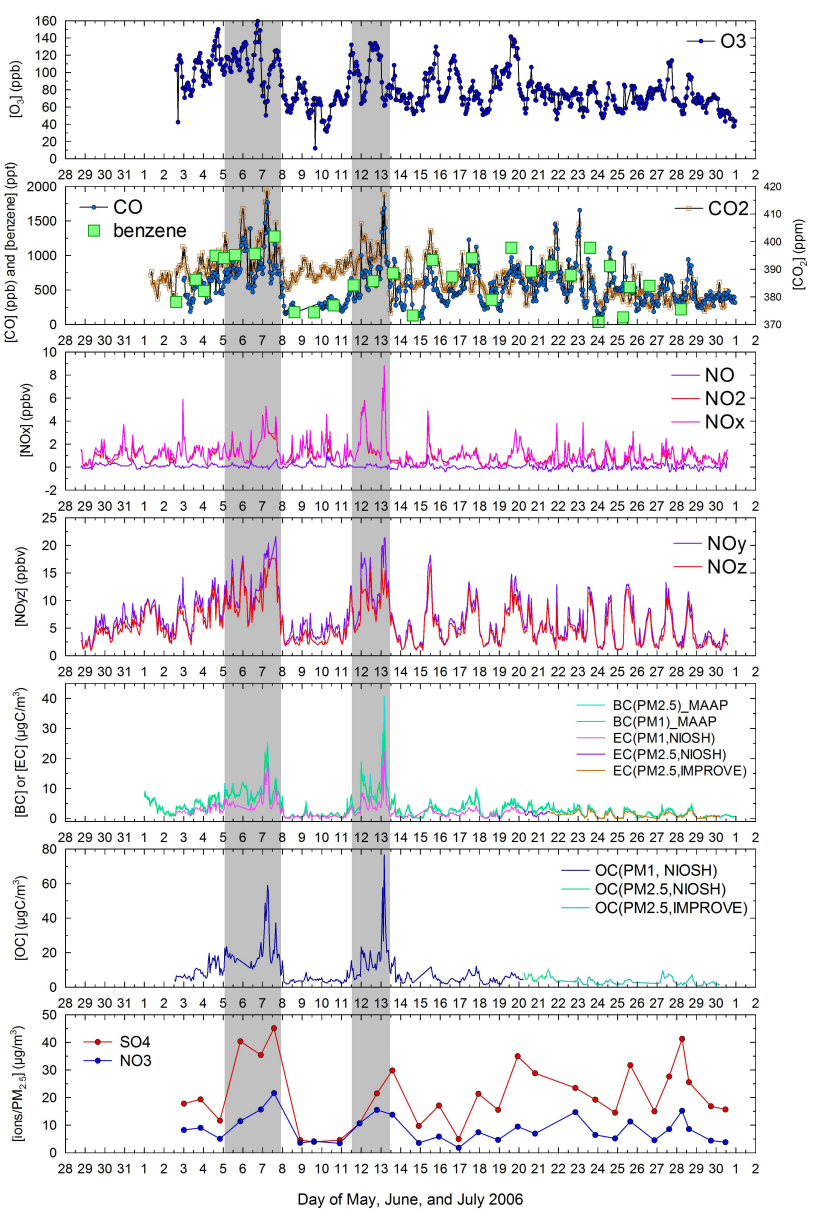

Fig. 3. Overall time series of $\mathrm{O}_{3}, \mathrm{CO}$, benzene, $\mathrm{CO}_{2}, \mathrm{NO}, \mathrm{NO}_{2}$, $\mathrm{NO}_{\mathrm{x}}, \mathrm{NO}_{\mathrm{y}}, \mathrm{NO}_{\mathrm{z}}, \mathrm{BC}, \mathrm{OC}$, sulfate, and nitrate. Hatched areas indicate two episodes with strong influences from OCRB.

at Mt. Tai, with average and maximum values of 6.7 and $21 \mathrm{ppbv}$, were much lower than those at Changping, i.e., 15 and $50 \mathrm{ppbv}$, respectively (T. Wang et al., 2006). The $\Delta \mathrm{CO} / \Delta \mathrm{NO}_{\mathrm{y}}$ ratio at Mt. Tai, around $50 \mathrm{ppbv}^{\mathrm{ppbv}}{ }^{-1}$, 

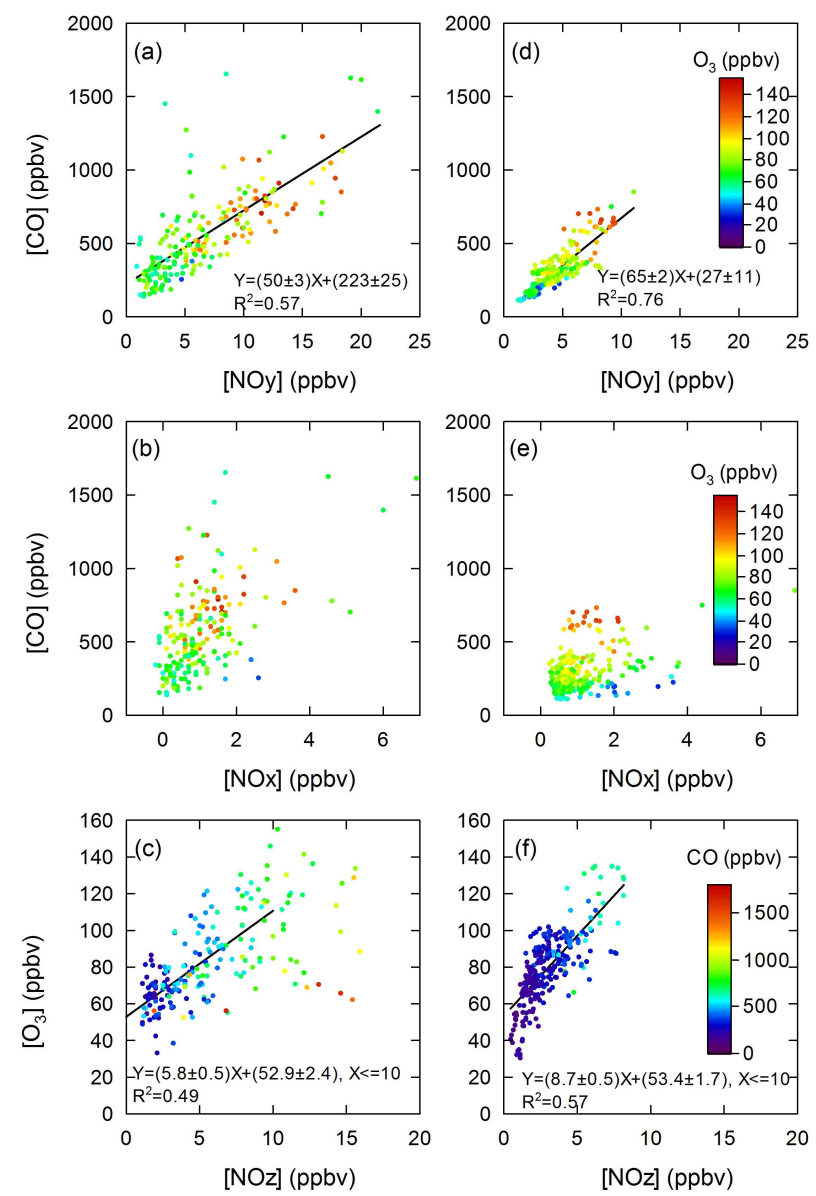

Fig. 4. Observed correlations between (a) $\mathrm{NO}_{\mathrm{y}}$ and $\mathrm{CO}$ concentrations, (b) $\mathrm{NO}_{\mathrm{x}}$ and $\mathrm{CO}$ concentrations, and (c) $\mathrm{NO}_{\mathrm{z}}$ and $\mathrm{O}_{3}$ concentrations. Symbols are colored by $\mathrm{O}_{3}$ concentrations for (a) and (b), and by $\mathrm{CO}$ concentrations for $\mathrm{CO}$. (d-f) same as (a-c) but using modeled concentrations.

shown as the slope of Fig. 4a, is 1.4 times that at Lin'an (3040, Wang et al., 2002, 2004), about twice that at Changping (20-30, T. Wang et al., 2006) and in a plume from Mexico City (20.6, Kleinman et al., 2008), and five or more times that in US vehicular emissions (6-10, Parrish et al., 2002; Parrish, 2006). The large $\Delta \mathrm{CO} / \Delta \mathrm{NO}_{\mathrm{y}}$ ratio at Mt. Tai could be attributed to open biomass burning. However, the ratio was similar for the latter half of the campaign, where the influence from biomass burning was minimal. Figure $4 \mathrm{~d}$ shows that the high $\Delta \mathrm{CO} / \triangle \mathrm{NO}_{\mathrm{y}}$ ratio is well reproduced by the CMAQ model simulation (Yamaji et al., 2010). Figure 4a and $\mathrm{d}$ also indicate that high $\mathrm{O}_{3}$ concentrations are associated with relatively high $\mathrm{CO}$ and $\mathrm{NO}_{\mathrm{y}}$ concentrations.

The median $\mathrm{NO}_{\mathrm{x}} / \mathrm{NO}_{\mathrm{y}}$ ratio of 0.15 , and the 15 and 85 percentile values of 0.07 and 0.27 at Mt. Tai, are much lower than the values at Miyun, predicted by a model to be $0.4-0.7$ (Wang et al., 2008a). Our range is even lower than that of the $\mathrm{NO}_{\mathrm{x}} / \mathrm{NO}_{\mathrm{y}}$ ratio reported by Kleinman et al. (2008) over the
Mexico City plateau of between 0.11 and 0.83 . From these findings, it was concluded that air at Mt. Tai is affected less by emissions of $\mathrm{NO}_{\mathrm{x}}$ but more by emissions of $\mathrm{CO}$, and is photochemically more aged, than is the case for air in studied regions surrounding the megacities of Beijing and Mexico City. It should be noted that CEC is not simply a source region; photochemical aging has great importance there.

The mean concentrations of BC $\left(\mathrm{PM}_{1}\right), \mathrm{EC}\left(\mathrm{PM}_{1}, \mathrm{NIOSH}\right.$ (National Institute for Occupational Safety and Health) temperature protocol, 2-20 June 2006), and OC (the same as EC) at Mt. Tai were 3.4, 2.6, and $9.2 \mu \mathrm{gC} \mathrm{m}^{-3}$, respectively (Fig. 3, Table 3). At Shangdianzi, the average BC mass concentration from April 2003 to January 2005 was $2.1 \mu \mathrm{gC} \mathrm{m}{ }^{-3}$ (Yan et al., 2008). The mass concentrations of $\mathrm{EC}$ and $\mathrm{PM}_{2.1}$ $\mathrm{OC}$ were found to be 1.3 and $5.1 \mu \mathrm{gC} \mathrm{m}^{-3}$ in summer 2004 (Yan et al., 2012). At Xianghe, located southeast of Beijing, Yang et al. (2009) reported that EC and OC mass concentrations were $\sim 5$ and $\sim 15 \mu \mathrm{gC} \mathrm{m}{ }^{-3}$ on average in March 2005. Lin et al. (2009) and Pathak et al. (2011) reported that the average concentrations of $\mathrm{EC}$ and $\mathrm{OC}$ were 4.5 and $10 \mu \mathrm{gC} \mathrm{m}^{-3}$ in Beijing in summer (June to September) 2006 and 4.9 and $8.2 \mu \mathrm{gC} \mathrm{m}{ }^{-3}$ at Changping in June-July 2005, which are comparable to those at Mt. Tai. However, it should be noted that time series plots of $\mathrm{BC}$ and $\mathrm{OC}$ at Mt. Tai show episodically very high concentration events, as seen in Fig. 3. Two prominent events during the periods 6-7 and 1213 June gave peak concentrations of 29 (22) and $77 \mu \mathrm{gC} \mathrm{m}^{-3}$ for $\mathrm{BC}(\mathrm{EC})$ and $\mathrm{OC}$, respectively; these can be ascribed to the plumes of OCRB, as will be described in Sect. 6.2.

The mean concentrations of $\mathrm{PM}_{2.5}$ and total suspended particles (TSP) during the campaign period were 123 and $135 \mu \mathrm{g} \mathrm{m}^{-3}$, respectively. These values are even higher than the average values of 78 and $115 \mu \mathrm{g} \mathrm{m}^{-3}$ observed in downtown Beijing in summer 2007 (Deng et al., 2011). The mass concentrations of sulfate and nitrate (both for $\mathrm{PM}_{2.5}$ ) during the campaign period were 21.0 and $8.5 \mu \mathrm{g} \mathrm{m}^{-3}$ (Deng et al., 2011), which were similar to 22.5 and $9.7 \mu \mathrm{g} \mathrm{m}^{-3}$ at Changping in June-July 2005 (Pathak et al., 2011).

In conclusion, $\mathrm{O}_{3}$ and aerosol concentration levels at the top of Mt. Tai are comparable to those in the outflow region or even the central urban area of Beijing, although photochemical age must be different. Such high concentrations would prevail over the central area of CEC.

The high pollutant concentrations recorded during this campaign are evident in the year-round observational records of $\mathrm{O}_{3}$ and $\mathrm{BC}$ at Mt. Tai (Fig. 5). The $\mathrm{O}_{3}$ concentration peaks in June at Mt. Tai in 2004, 2005, and 2006 are all steep. The peak timings are generally later than those at Mt. Huang and Mt. Hua, mentioned earlier (see locations in Fig. 1), and that at Mondy in East Siberia, Russia $\left(51.66^{\circ} \mathrm{N}, 101.00^{\circ} \mathrm{E}\right.$, $2000 \mathrm{~m}$ a.s.1.), an EANET (acid deposition monitoring network in East Asia) background remote site. The BC concentrations at Mt. Tai and Mt. Huang were high in winter, spring, and autumn, and low in summer (Fig. 5b). The BC concentration levels were higher at Mt. Tai than at Mt. Huang 

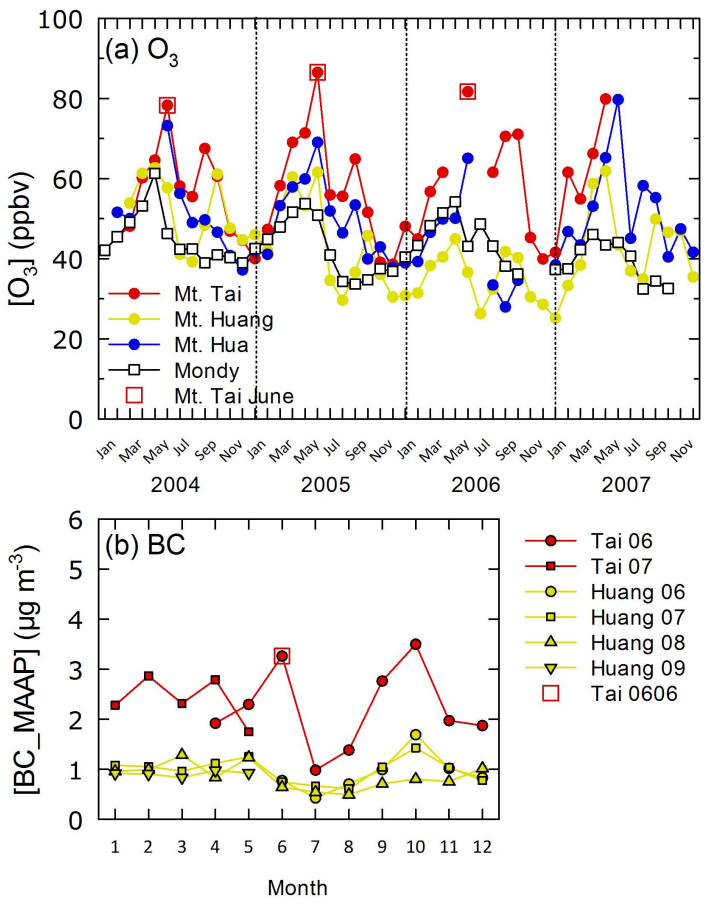

Fig. 5. Year-round observations of (a) $\mathrm{O}_{3}$ and (b) BC at Mt. Tai and other mountain sites. Data for Mt. Tai in June are surrounded by squares.

throughout the year. The BC level at Mt. Tai in June 2006 was one of the highest monthly averages.

Figure 6 shows the average diurnal variations of selected species. Ozone showed a broad peak in the late afternoon (14:00-19:00 LT) as high as 92-94 ppbv. $\mathrm{NO}_{\mathrm{y}}$ and $\mathrm{CO}$ had earlier peaks in the afternoon, coinciding with the transport of pollutants from lower altitudes with respect to the buildup of the boundary layer. The peak of BC in the early morning (04:00-06:00 LT) was influenced by very high concentrations occurred in these hours on 7 and 13 June, which are ascribed to OCRB. After 16 June, $\mathrm{O}_{3}, \mathrm{CO}, \mathrm{NO}_{\mathrm{y}}$, and $\mathrm{BC}$ commonly showed diurnal patterns with single afternoon peaks (Fig. 6). For $\mathrm{O}_{3}$ and $\mathrm{BC}$, the amplitudes of the daytime increase for this period are similar to those for the whole period, while the concentration levels are lower. For $\mathrm{CO}$ and $\mathrm{NO}_{\mathrm{y}}$, the daytime peak concentrations and the amplitudes of the diurnal variations are larger after 16 June. OC showed relatively flat diurnal variations in the early period (until 20 June, when the NIOSH temperature protocol was used with $\mathrm{PM}_{1}$ sampling), but showed regular diurnal variations with early afternoon maxima in the latter period, when an IMPROVE (Interagency Monitoring of Protected Visual Environments)-like protocol was used with $\mathrm{PM}_{2.5}$ sampling. $\mathrm{CO}_{2}$ showed a regular daytime decrease, mainly in response to the source/sink provided by vegetation. Figure 7 shows three photographs looking westward from the observatory at the summit of Mt. Tai. In the upper panel, the outlines of dis-
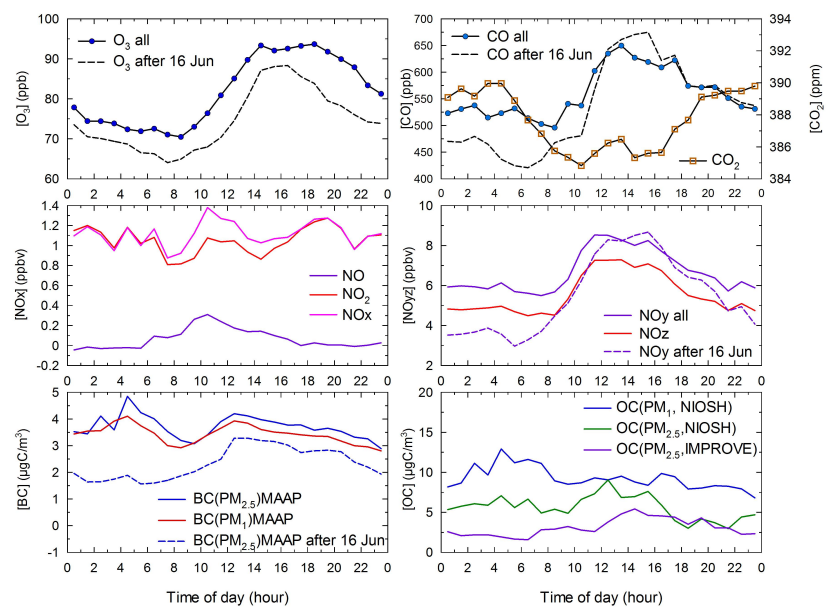

Fig. 6. Average diurnal variations in $\mathrm{O}_{3}, \mathrm{CO}, \mathrm{CO}_{2}, \mathrm{NO}, \mathrm{NO}_{2}, \mathrm{NO}_{\mathrm{x}}$, $\mathrm{NO}_{\mathrm{y}}, \mathrm{NO}_{\mathrm{z}}, \mathrm{BC}$, and $\mathrm{OC}$ concentrations during the whole MTX2006 campaign period (solid lines). Dashed lines are for the latter half period after 16 June.

tant mountains about $5 \mathrm{~km}$ away (labeled as B-D) are clearly visible, when aerosols are not abundantly present. Once regional pollution occurs, as shown in the middle panel, the top boundary of the polluted layer is clearly visible below the mountain altitude level in the morning. The distant mountains (B-D) became invisible, and the nearby peak about 900 $\mathrm{m}$ away (labeled as $\mathrm{A}$ ) is also masked by haze. The pollution layer develops in the later hours, as shown in the bottom panel, and then the mountain top is incorporated in the polluted layer, at around noontime.

The high concentrations of $\mathrm{BC}$ must have important implications for the regional climate in CEC. Here, the RF is roughly estimated. First, we simply estimate its column concentration $\left(5.2 \mathrm{mg} \mathrm{m}^{-2}\right)$ by multiplying the monthly mean concentration $\left(3.4 \mu \mathrm{gC} \mathrm{m}^{-3}\right)$ observed at the mountain top by the altitude (i.e., $1534 \mathrm{~m}$ ), assuming a box-shaped vertical profile. Then, by multiplying a factor of 0.85 , assuming that $85 \%$ of BC is anthropogenic (Bond et al., 2011), and a sensitivity factor $\left(1.25 \mathrm{~W} \mathrm{mg}^{-1}\right.$, IPCC, 2007), we obtain an $\mathrm{RF}$ as high as $5.5 \mathrm{~W} \mathrm{~m}^{-2}$. Although only roughly estimated, this value far exceeds the RF from $\mathrm{CO}_{2}$, estimated to be $\sim 1.6 \mathrm{~W} \mathrm{~m}^{-2}$. The regional-scale $\mathrm{BC}$ air pollution therefore greatly affects the radiative budget. More detailed studies using radiative transfer models and chemistry-climate coupled models are needed.

\subsection{Importance of OCRB and regional transport}

Figure 8 shows backward trajectories starting from 1500 and $750 \mathrm{~m}$ at Mt. Tai for six selected times: 12:00 LT on 6, 9, $12,14,19$, and 27 June 2006. The kinematic backward trajectories were calculated using the CGER-METEX program (http://db.cger.nies.go.jp/metex/), using the National Centers for Environmental Prediction meteorological reanalysis field 

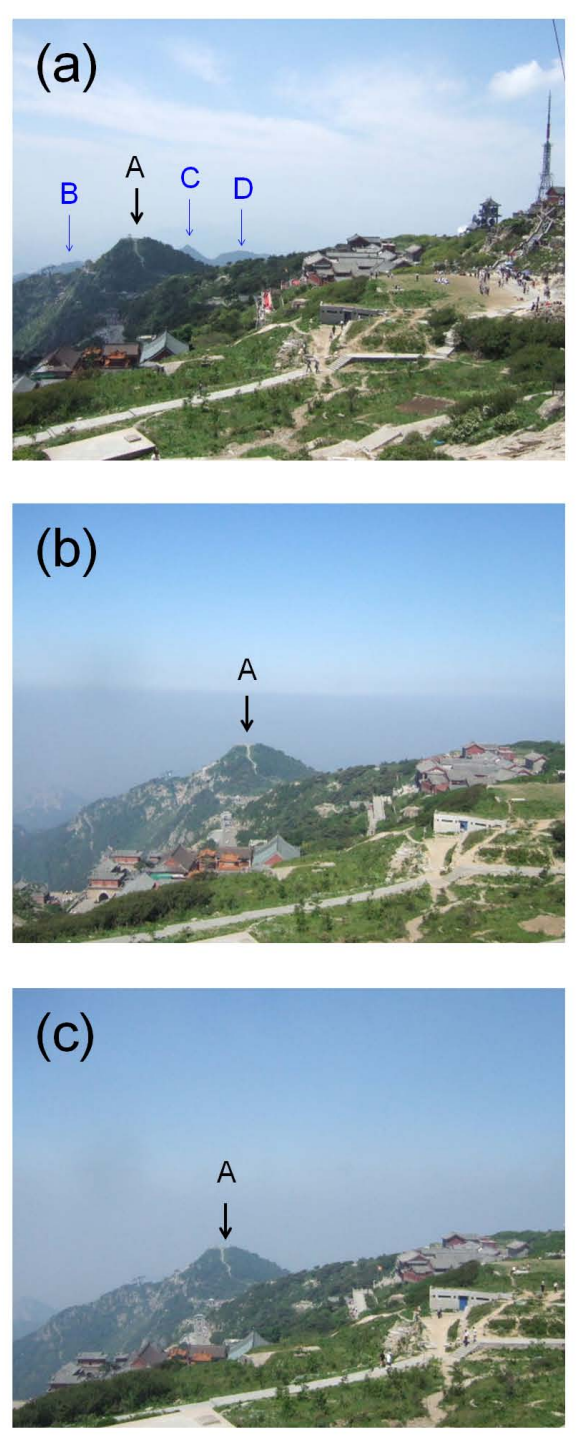

Fig. 7. Photographs taken from the observatory looking westward. (a) Day with good visibility. (b) Pollution layer seen below the mountain in the morning. (c) Polluted boundary layer builds up in the morning and covers the mountain top before noon.

as input. They are shown together with geographical distributions of hotspots detected by sensors on board NOAA and FY-1D satellites during the preceding five days. The colorcoded map shows the winter-wheat harvesting period. These figures are based on those produced by SEPA (State Environmental Protection Administration, currently Ministry of the Environment) of the Chinese government. As seen in Fig. 8, the winter-wheat harvesting region shifts from the southern part in April/May to northern and western areas in June/July. June is the most active burning season south of Mt. Tai, after the harvesting of winter wheat. Figure 3, particularly for BC and OC, clearly shows more polluted days in the first half and cleaner days in the latter half of the campaign period. Two prominent pollution episodes are seen during the periods 67 June and 12-13 June, when the backward trajectory passed over the burnt areas. These characteristics strongly suggest the impact of OCRB on air quality at Mt. Tai. Suthawaree et al. (2010), Yamaji et al., (2010), and Fu et al. (2012), on this issue, similarly report the impact of burning using backward trajectories that passed over hotspots. On 8-10 June, the wind was from the north and thus the influence was small, although hotspots were continuously found south of Mt. Tai. Pan et al. $(2012,2013)$ combined the geographical distribution of the hotspots with backward Weather Research and Forecasting (WRF)-FLEXPART model simulations and found that the influential source area was $33-34^{\circ} \mathrm{N}$ and $116-118^{\circ} \mathrm{E}$, about $300 \mathrm{~km}$ south of the observatory. They also suggested that the transport time of the air mass from the source region ranged from 10 to $50 \mathrm{~h}$. The observed evidence of burning, in addition to high $\mathrm{CO}$ and $\mathrm{BC}$ concentrations, were elevated concentrations of levoglucosan and other anhydrosugars (Fu et al., 2008), $\mathrm{K}^{+}$, and oxalic acid in $\mathrm{PM}_{2.5}$ (Xu et al., 2009; Deng et al., 2011), $\mathrm{CH}_{3} \mathrm{Cl}$ (Suthawaree et al., 2010), $\mathrm{CH}_{3} \mathrm{CN}$ (Inomata et al., 2010), and lowered stable carbon isotope ratios $\left(\delta^{13} \mathrm{C}\right)$ of organic aerosol particles (Fu et al., 2012). Figure 9 simultaneously shows their temporal variations.

The impact of OCRB on $\mathrm{O}_{3}, \mathrm{CO}, \mathrm{BC}$, and $\mathrm{OC}$ concentrations over CEC during MTX2006 was evaluated using a regional chemical transport model, CMAQ, employing estimated daily emissions from OCRB, based on hotspot data obtained by MODIS (Yamaji et al., 2010). The impact of OCRB on regional emissions during the period 6-9 June amounted to $31-44 \%\left(\mathrm{NO}_{\mathrm{x}}\right), 47-61 \%(\mathrm{CO}), 50-63 \%$ (EC), and 56-69\% (primary organic aerosols) of the total sources in CEC. After 17 June, the impact of OCRB was almost zero. Figure 6 in Yamaji et al. (2010) demonstrates that the daily emissions from OCRB conveyed by southerly winds were an essential factor in reproducing atmospheric concentrations of pollutants during MTX2006. These emissions have a large impact not only on primary pollutants but also on secondary pollutants, such as $\mathrm{O}_{3}$, in the first half of June. The run with OCRB emissions (06DS) clearly captured the observed variations in daily average $\mathrm{O}_{3}$ concentrations, with a correlation coefficient $R$ of 0.61 between the model and the observations, which is much better than that obtained without burning (NOCRB; $R=0.34$ ). The monthly $\mathrm{O}_{3}$ concentration simulated using 06DS (80.8 ppbv) was much closer than that obtained using NOCRB (73.9 ppbv) to the observed monthly $\mathrm{O}_{3}$ concentration. The average impacts of OCRB emissions contributed $6 \%$ of $\mathrm{O}_{3}, 20 \%$ of $\mathrm{CO}, 43 \%$ of $\mathrm{EC}$, and $53 \%$ of OC concentrations over CEC for the whole month of June; for the episodic period 6-9 June, the impacts increased to $12 \%$ for $\mathrm{O}_{3}, 35 \%$ for $\mathrm{CO}, 56 \%$ for $\mathrm{BC}$ daily emissions, and $80 \%$ for OC over CEC. The real cause of the sharp rise in the $\mathrm{O}_{3}$ concentrations in June at Mt. Tai (Fig. 5a), which had been a mystery, was therefore identified as biomass burning, by conducting a comprehensive field campaign covering the precursors of $\mathrm{O}_{3}$ and related species. 

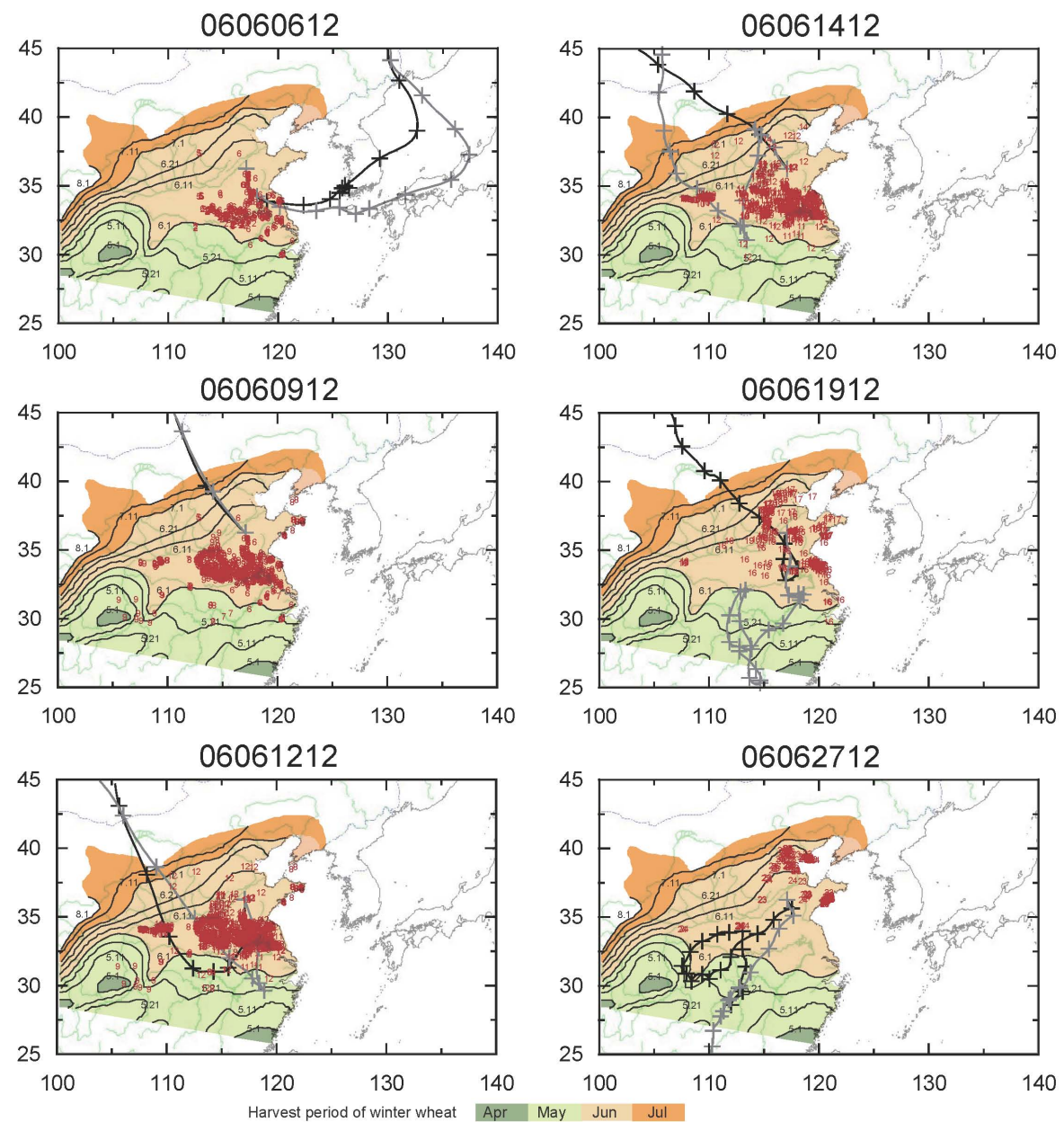

Fig. 8. Backward trajectories with starting altitudes of 1500 (black) and $750 \mathrm{~m}$ (gray) at six different times (YYMMDDHH in LT, shown above individual panels). Plus marks indicate the locations of air mass every $12 \mathrm{~h}$. Hotspots detected by satellite sensors during the 5 preceding days are shown in red (numbers indicate the detection day in June). Harvest areas of winter wheat in different months are shown by colored areas.

\subsection{Attribution of near-ground $\mathrm{O}_{3}$ over Mt. Tai to the transport from other source regions}

A regional chemical transport model, NAQPMS, with an online tracer tagging module, was used to study the source areas of near-ground $\mathrm{O}_{3}$ at Mt. Tai during the MTX2006 period (Li et al., 2008a). During this time period, CEC was covered with air masses with high $\mathrm{O}_{3}$ concentrations (65$85 \mathrm{ppbv}$ ) in the model simulation. Mt. Tai was at the center of a high- $\mathrm{O}_{3}$ region with the prevailing wind from the south. The source regions were divided into CEC and outer regions (Fig. 1b, see also Fig. 1 of $\mathrm{Li}$ et al., 2008a). The former consists of Local, South, East, and North Shandong (SSD, ESD, and NSD), Hebei/Beijing/Tianjin (HBT), Shanxi (SX), Henan (HN), Anhui (AH), Jiangsu (JS), and East China Sea (CHNSEA). The latter consists of Siberia (SIB), Northwest China (NWCHN), Southwest China (SWCHN), South China (SCHN), East China (ECHN), Northeast China (NECHN), the western Pacific rim (PAC), Korea (KOR), Japan (JPN), and Southeast Asia (SEASA). The "Local" represents a region including Tai' an and Laiwu cities and Mt. Tai, with a $1 \times 10^{5} \mathrm{~km}^{2}$ area. Source attributions from the regional scale down to sub-province levels were therefore made.

In general, regional photochemical production of $\mathrm{O}_{3}$ within CEC was the most important mechanism, showing a contribution of $51.4 \mathrm{ppbv}(60.2 \%)$ to a monthly mean $\mathrm{O}_{3}$ mixing ratio (on a $24 \mathrm{~h}$ basis) of $85.4 \mathrm{ppbv}$ ( $\mathrm{Li}$ et al., 2008a). Specifically, the largest fractions of $\mathrm{O}_{3}$ were formed in SSD, AH, and JS (32.4 ppbv or $37.9 \%$ ), influenced by high emission rates (including those from biomass burning) and favorable meteorological conditions in these areas. They concluded that local photochemical production $(9.8 \mathrm{ppbv}$ or $11.5 \%)$ is a minor contribution, suggesting that emissions from local cities (e.g., Tai'an) could be of minor importance. The calculated in situ $\mathrm{O}_{3}$ production rate was in good 


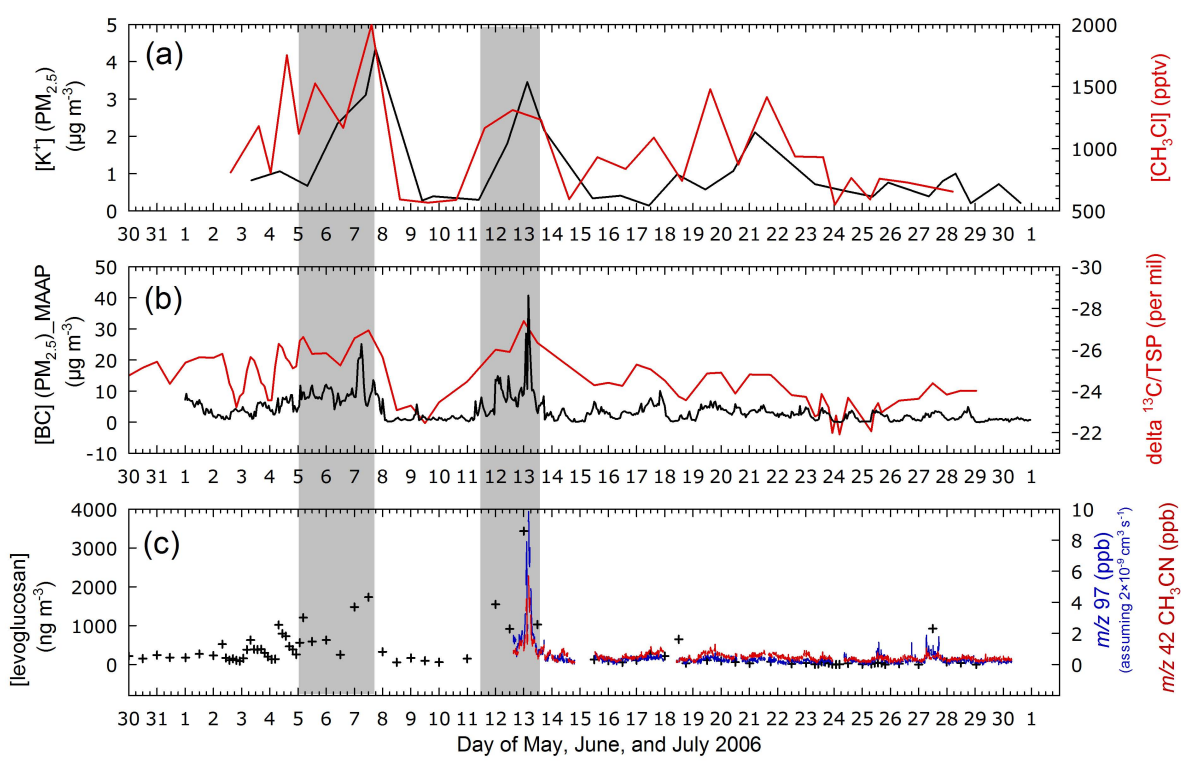

Fig. 9. Time series of selected biomass burning tracers. Hatched areas indicate two episodes with strong influences from OCRB. Panel (c) shows correlations between levoglucosan concentrations from TSP filter samples (plus marks) and $m / z 97$ and $m / z 42\left(\mathrm{CH}_{3} \mathrm{CN}\right)$ signals (colored solid lines) derived from continuous PTR-MS measurements.

agreement with the results of Kanaya et al. (2009), which will be described in Sect. 6.4.

$\mathrm{Li}$ et al. (2008b) showed that the same NAQPMS model was able to reproduce the observed diurnal variations in $\mathrm{O}_{3}$ at Mt. Tai, and studied the roles of chemical production and vertical transport. They suggested that the photochemistry in the surrounding region accounted for most of the increases in $\mathrm{O}_{3}$ mixing ratios from morning to mid-afternoon and that the role of vertical transport was minor. Li et al. (2011), using a similar model framework, studied the impact of aerosols on $\mathrm{O}_{3}$ photochemistry through the reduction of ultraviolet (UV) radiation over this period, with a strong influence from biomass burning. They estimated that the $J\left(\mathrm{O}^{1} \mathrm{D}\right)$ values and $\mathrm{OH}$ concentrations are reduced by 37 and $40 \%$, respectively, in the middle troposphere over $\mathrm{CEC}$, leading to lower $\mathrm{O}_{3}$ concentrations (by a maximum of $9 \%$ in highly polluted regions).

\subsection{Photochemical $\mathrm{O}_{3}$ production processes over CEC in June 2006}

An observation-based box-model approach was undertaken to estimate concentrations of $\mathrm{OH}, \mathrm{HO}_{2}$, and $\mathrm{RO}_{2}$ radicals, and the net photochemical production rate of $\mathrm{O}_{3}$, i.e., $\mathrm{F}-$ $D\left(\mathrm{O}_{3}\right)$, the difference between the rates of gross formation $\left[F\left(\mathrm{O}_{3}\right)\right]$ and loss $\left[D\left(\mathrm{O}_{3}\right)\right]$ (Kanaya et al., 2009). The model calculation was constrained by measurements of $\mathrm{O}_{3}, \mathrm{H}_{2} \mathrm{O}$, $\mathrm{CO}, \mathrm{NO}, \mathrm{NO}_{2}$, hydrocarbons, $\mathrm{HCHO}$, and $\mathrm{CH}_{3} \mathrm{CHO}$ concentrations, and temperature and $J$ values. Figure 3 of Kanaya et al. (2009) shows the calculated $F\left(\mathrm{O}_{3}\right), D\left(\mathrm{O}_{3}\right)$ and $F-D\left(\mathrm{O}_{3}\right)$ separately for high- $\mathrm{O}_{3}$ days, with at least one hour exceed- ing $100 \mathrm{ppbv}$, and low- $\mathrm{O}_{3}$ days (all hourly values are below $100 \mathrm{ppbv}$ ), and they argued that the difference was not large, suggesting that $\mathrm{O}_{3}$ transportation is more important than in situ photochemistry for accumulation of $\mathrm{O}_{3}$ to $>100 \mathrm{ppbv}$. The net production rate of $\mathrm{O}_{3}$ was estimated to be $6.4 \mathrm{ppbv}$ $\mathrm{h}^{-1}$ as a $6 \mathrm{~h}$ average (09:00-15:00 LT), in rough agreement with the in situ production rate $\left(\sim 5 \mathrm{ppbvh}^{-1}\right)$ estimated in a three-dimensional regional-scale modeling study ( $\mathrm{Li}$ et al., 2008b). These values fall within the range of the rates estimated for the boundary layer over major cities in the United States, 3.5-11.3 $\mathrm{ppbv} \mathrm{h}^{-1}$ (Kleinman et al., 2002).

The estimated $6 \mathrm{~h}$ averages of $F-D\left(\mathrm{O}_{3}\right)$ suggest that $58 \pm 37 \mathrm{ppbv}$ of $\mathrm{O}_{3}$ are potentially produced in 1 day (Kanaya et al., 2009). A sensitivity model run was made, incorporating heterogeneous loss of $\mathrm{HO}_{2}$ on aerosol particle surfaces, which could impede photochemical $\mathrm{O}_{3}$ production. Pure water extracts of aerosol samples collected on quartz filters were used to regenerate aerosol particles in an aerosol flow tube in the laboratory, to study the loss kinetics of $\mathrm{HO}_{2}$ radicals as a result of heterogeneous reactions on the aerosol particles (Taketani et al., 2012). The uptake coefficients $(\gamma$ values), determined for real atmospheric aerosol particle samples (> 10 samples) for the first time, had an average value of 0.25 , larger than the values determined for particles with major single components (e.g., ammonium sulfate), suggesting the possibility that minor components of aerosols play important roles. When this heterogeneous loss of $\mathrm{HO}_{2}$ was included with an assumption that $\mathrm{H}_{2} \mathrm{O}_{2}$ was not produced, although still uncertain (Mao et al., 2013), the daily integral of $F-D\left(\mathrm{O}_{3}\right)$ fell from 58 to $39 \mathrm{ppbv}$. This quantity was still larger than the observed daytime increases in the 
$\mathrm{O}_{3}$ concentration observed at the mountain top, $23 \mathrm{ppbv}$ on average (Fig. 6), suggesting that the daytime buildup could be still explained by photochemistry. Another sensitivity box model run with altered $\mathrm{NO}_{\mathrm{x}}$ and hydrocarbon concentrations by $10 \%$ (Kanaya et al., 2009) suggested that $\mathrm{O}_{3}$ production occurred normally under $\mathrm{NO}_{\mathrm{x}}$-limited conditions. Here we show in Fig. $4 \mathrm{~b}$ that $\mathrm{NO}_{\mathrm{x}}$ is almost depleted by photochemical aging (in comparison with Fig. $4 \mathrm{a}$, using $\mathrm{NO}_{\mathrm{y}}$ as the $x$ axis), and thus the abundance of NMHCs, correlated with $\mathrm{CO}$ and used for the $y$ axis in Fig. 4b, becomes relatively high, resulting in $\mathrm{NO}_{\mathrm{x}}$-limited conditions. This is consistent with the box-model analysis (Kanaya et al., 2009). An exception was 10 June, when fresh pollution from the north affected the site and the $\mathrm{O}_{3}$ production was VOC limited (Kanaya et al., 2009). This analysis suggests that the $\mathrm{O}_{3}$ pollution over the CEC region will become even worse when $\mathrm{NO}_{\mathrm{x}}$ emissions increase in the future. Here we also show in Fig. 4e the modeled dependence of $\mathrm{O}_{3}$ on $\mathrm{NO}_{\mathrm{x}}$ and $\mathrm{CO}$. Although the modeled dependence is similar to the observations (Fig. 4b), the model tends to underestimate $\mathrm{CO}$ and therefore the $\mathrm{CO} / \mathrm{NO}_{\mathrm{x}}$ ratio. Because the $\mathrm{O}_{3}$ concentration is positively dependent on the CO concentration (see color codes in Fig. 4e and b), an increase in $\mathrm{CO}$ in the model to reproduce the observed levels will increase the $\mathrm{O}_{3}$ concentration.

Figure $4 \mathrm{c}$ shows that hourly $\mathrm{O}_{3}$ concentrations increase with $\mathrm{NO}_{\mathrm{z}}\left(\left[\mathrm{NO}_{\mathrm{z}}\right]=\left[\mathrm{NO}_{\mathrm{y}}\right]-[\mathrm{NO}]-\left[\mathrm{NO}_{2}\right]\right)$ up to about 10 ppbv, but saturation occurs with further increases in $\mathrm{NO}_{z}$. This feature is consistent with the above-mentioned analysis using a box model, which suggested general $\mathrm{NO}_{\mathrm{x}}$-limited conditions (Kanaya et al., 2009). The slope $\Delta\left[\mathrm{O}_{3}\right] / \Delta\left[\mathrm{NO}_{\mathrm{z}}\right]$ was $5.8 \pm 0.5 \mathrm{ppbv}^{\mathrm{ppbv}}{ }^{-1}$ when the $\mathrm{NO}_{\mathrm{z}}$ mixing ratio was below 10 ppbv, implying efficient $\mathrm{O}_{3}$ production from $\mathrm{NO}_{\mathrm{x}}$. This is quite similar to the value of 3-6 ppbv ppbv ${ }^{-1}$ suggested for selected episodes studied at Changping, near Beijing under $\mathrm{NO}_{\mathrm{x}}$-limited conditions (T. Wang et al., 2006), and to that of $6.2 \mathrm{ppbv} \mathrm{ppbv}^{-1}$ found for the Pico de Tres Padres (PTP) site near Mexico City (Wood et al., 2009). The observed slope is lower than the modeled slope (Fig. 4f, slope $\left.=8.7 \pm 0.5 \mathrm{ppbv} \mathrm{ppbv}^{-1}\right)$. This suggests either that the $\mathrm{O}_{3}$ production efficiency per unit $\mathrm{NO}_{\mathrm{x}}$ molecule oxidation is slightly lower than that predicted by the model or that the model underestimated formation of $\mathrm{NO}_{\mathrm{z}}$. Although not shown, high $\mathrm{O}_{3}$ concentrations are sometimes associated with aged air masses $\left(\ln \left(\left[\mathrm{NO}_{\mathrm{y}}\right] /\left[\mathrm{NO}_{\mathrm{x}}\right]\right)>2\right.$ or $\left.\left[\mathrm{NO}_{\mathrm{x}}\right] /\left[\mathrm{NO}_{\mathrm{y}}\right]<0.14\right)$.

Figure 10 shows the comparison between the observed average diurnal variation in the $\mathrm{NO} / \mathrm{NO}_{2}$ ratio and those in the three theoretical values derived from photostationary state analyses, considering NO-to- $\mathrm{NO}_{2}$ conversion by $\mathrm{O}_{3}$ only (ratio A) and by $\mathrm{O}_{3}$ and peroxy radicals whose concentrations were calculated in the box model run (ratio B), with and without heterogeneous loss of $\mathrm{HO}_{2}$, respectively, for the first-half period (till 15 June):

ratio $A=J\left(\mathrm{NO}_{2}\right) /\left(k_{1}\left[\mathrm{O}_{3}\right]\right)$

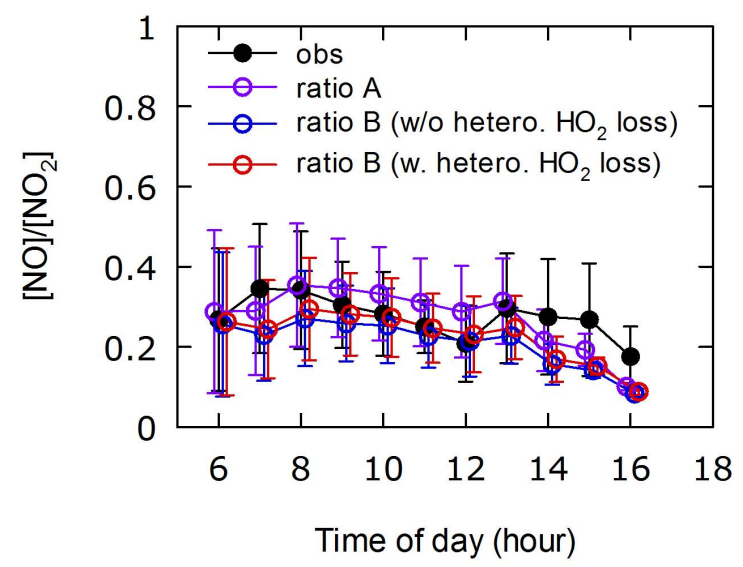

Fig. 10. Average diurnal variations of the observed $\mathrm{NO} / \mathrm{NO}_{2}$ ratio (black) compared with theoretical values assuming photostationary states for the first-half period (till 15 June). For the theoretical values, observed $J\left(\mathrm{NO}_{2}\right)$ and $\mathrm{O}_{3}$ concentrations, and peroxy radical concentrations calculated with box model simulations were used. The error bars represent $1 \sigma$ ranges of day-to-day variations. See Sect. 6.4 for more details.

ratio $B=J\left(\mathrm{NO}_{2}\right) /\left(k_{1}\left[\mathrm{O}_{3}\right]+k_{2}\left[\mathrm{HO}_{2}\right]+\Sigma k_{3 i}\left[\mathrm{RO}_{2}\right]_{i}\right)$,

where $k_{1-3}$ are the rate coefficients of the NO reactions with $\mathrm{O}_{3}, \mathrm{HO}_{2}$, and $\mathrm{RO}_{2}$ (organic peroxy radicals), respectively. The observed daytime $\mathrm{NO} / \mathrm{NO}_{2}$ ratios are typically in the range of $0.2-0.4$, relatively lower than other field studies. As first approximation, this is virtually explained by very high $\mathrm{O}_{3}$ concentrations converting $\mathrm{NO}$ to $\mathrm{NO}_{2}$ efficiently. Figure 10 shows that the observed $\mathrm{NO} / \mathrm{NO}_{2}$ levels agreed fairly well with the three calculations within uncertainty (typically 21 and $24 \%(1 \sigma)$ for ratios A and B, respectively), including the ratio $\mathrm{B}$ considering heterogeneous loss of $\mathrm{HO}_{2}$.

\section{5 $\mathrm{NO}_{2}$ measurements by MAX-DOAS: comparisons with satellite and in situ observations}

During the campaign period, MAX-DOAS measurements of vertical profiles of $\mathrm{NO}_{2}$ were performed from the top of Mt. Tai as well as from the foothills in the city of Tai' an (Irie et al., 2008). The mean difference between the $\mathrm{NO}_{2}$ volume mixing ratios measured by MAX-DOAS instruments at Tai' an and Mt. Tai and from in situ data based on chemiluminescence detection coupled with a photolytic converter were as small as $-0.01 \pm 0.60$ and $-0.29 \pm 0.65 \mathrm{ppbv}$, respectively (see Fig. 5 of Irie et al., 2008). The mean $\mathrm{NO}_{2}$ volume mixing ratio for the $0-1 \mathrm{~km}$ altitude layer above the surface derived from the MAX-DOAS measurements at Tai' an was about 4 ppbv.

The MAX-DOAS measurements showed complete diurnal variations in the tropospheric $\mathrm{NO}_{2} \mathrm{VCD}$ in the daytime. Typically, the value was highest, at $\sim 15 \times 10^{15}$ molecules $\mathrm{cm}^{-2}$, in the early morning (06:00-09:00 LT) and dropped to a minimum of $\sim 7 \times 10^{15}$ molecules $\mathrm{cm}^{-2}$ at 13:00-15:00 LT. This 
indicates that the OMI measurements (at about 13:40 LT) were made when the tropospheric $\mathrm{NO}_{2} \mathrm{VCD}$ was lowest in its typical diurnal cycle, and that the systematic difference between tropospheric $\mathrm{NO}_{2}$ VCDs derived from OMI and those observed by SCIAMACHY and GOME2 in the morning could be explained by this strong diurnal variation. Critical comparisons between tropospheric $\mathrm{NO}_{2} \mathrm{VCDs}$ derived from MAX-DOAS and OMI were made for the first time in CEC, with different spatial coincidence criteria. It was revealed that the use of a stricter coincident criterion of $0.1^{\circ}$ resulted in better agreement, within $(+1.6 \pm 0.6) \times 10^{15}$ molecules $\mathrm{cm}^{-2}(+20 \pm 8 \%)$ (OMI minus MAX-DOAS).

\subsection{Volatile organic compound and oxygenated volatile organic compound (VOC/OVOC) compositions and concentrations}

The relative concentration ratios of individual NMHCs (10 alkanes, six aromatic compounds, seven alkenes, and acetylene), normalized by ethane, at Mt. Tai, derived from daily canister sampling followed by gas chromatography-flame ionization detector analysis, were compared with those observed in the Beijing city center on 20 November 2005 (see Fig. 7 of Suthawaree et al., 2010). Here, the average concentration of ethane at Mt. Tai was $2.4 \mathrm{ppbv}$, comparable to those in other areas of China (Barletta et al., 2005), reflecting its long lifetime and the absence of local sources. As expected, they found that the ratios of major alkanes and alkenes to ethane are much lower for observations at Mt. Tai than they are in Beijing, reflecting the fact that the air mass at Mt. Tai is isolated from sources and is more aged. The measured benzene/toluene ratio at Mt. Tai was $3.2 \pm 1.0$, much higher than those (0.6) for other Chinese cities (Barletta et al., 2005) and other parts of the world, where vehicular emissions make significant contributions. A high ratio to ethane was also found for acetylene, probably reflecting the contribution of biomass/biofuel combustion in the surrounding areas. The analysis of halogenated compounds $\left(\mathrm{C}_{2} \mathrm{Cl}_{4}\right.$, $\mathrm{CH}_{3} \mathrm{Cl}, \mathrm{CH}_{3} \mathrm{Br}$ ) by gas chromatography-mass spectrometry and flame ionization detection showed low concentrations of $\mathrm{C}_{2} \mathrm{Cl}_{4}, 8$ pptv on average, suggesting insignificant impacts of industrial emissions, and relatively high concentrations of $\mathrm{CH}_{3} \mathrm{Cl}, 990 \mathrm{pptv}$ on average, suggesting the influence of biomass burning (Fig. 9a). The isoprene concentrations were 209 pptv on average $(n=25)$ for daytime samples (collected at $\sim 14: 40 \mathrm{LT}$ ), suggesting that biogenic activity was moderate and less active than in other mountainous areas in China (e.g., 480 pptv at Mt. Jianfeng; Tang et al., 2007).

Real-time measurements of NMHCs and OVOCs were made using a PTR-MS (proton-transfer reaction-mass spectrometry) instrument during the period 12-30 June 2006, the latter half of the campaign period (Inomata et al., 2010). One of their major findings is that the observed mixing ratios of acetaldehyde were approximately 1.6 times higher than those of formaldehyde during the whole observation period. This is in contrast to the finding that the mixing ratios of formaldehyde are generally higher than those of acetaldehyde in Beijing (Shao et al., 2009) and other urban, suburban, and rural sites in the world, suggesting the possibility of primary emission of acetaldehyde. The concentrations of methanol were high, $\sim 10 \mathrm{ppbv}$ on average, compared with aldehydes and acetone. This result is similar to that observed in Beijing (Liu et al., 2009) and near that of biomass burning (Karl et al., 2007). The HCHO concentrations derived from PTRMS were in good agreement with those from MAX-DOAS observations (Inomata et al., 2008).

Here we newly show that the PTR-MS signal at $\mathrm{m} / z$ 97 showed a strong positive correlation $(R=0.95)$ with levoglucosan concentrations in the TSP samples (Fig. 9c). See Fu et al. (2008) for details of the analysis of levoglucosan. The correlation coefficient was even larger than that for $\mathrm{CH}_{3} \mathrm{CN}$ and levoglucosan $(R=0.89)$. Karl et al. (2007) studied tropical biomass burning and assigned the peaks at $m / z 97$ to substituted furans and furfurals. This may be valid for our study. However, our $(m / z$ 97) $/(m / z 42)$ ratio of $1.6 \mathrm{ppbv} \mathrm{ppbv}^{-1}$ was slightly lower than the value of $2.4-$ $3.2 \mathrm{ppbv} \mathrm{ppbv}^{-1}$ reported by Karl et al. (2007); this suggests that either the furans were removed by fast $\mathrm{OH}$ reactions during travel for $10-50 \mathrm{~h}$, and the original emission ratio was much higher, or that the species we detected at $m / z 97$ was different and had more chemical stability, resulting in the high correlation coefficient. Additionally, $\mathrm{m} / \mathrm{z} 85$ and $\mathrm{m} / \mathrm{z}$ 87 also showed strong correlations $(R>0.90)$ with levoglucosan; the $(m / z 85) /(m / z 42)$ and $(m / z 87) /(m / z 42)$ ratios were 1.2 and $1.6 \mathrm{ppbv} \mathrm{ppbv}^{-1}$, respectively, assuming a typical ion-molecule reaction rate constant of $2 \times 10^{-9} \mathrm{~cm}^{3}$ molecules ${ }^{-1} \mathrm{~s}^{-1}$. These analyses were made possible by the comprehensive coverage of gas and aerosol species during this MTX2006 field campaign. More studies are needed in the vicinity of biomass-burning sources for better characterization.

Kawamura et al. (2013a) used a two-step filter cartridge sampler to collect particulate and gaseous carbonyls on quartz filters (impregnated with O-benzylhydroxylamine (BHA) for gas collection) and analyzed them with a gas chromatograph after derivatization. The gas-phase concentrations of glycolaldehyde (range $0-1271 \mathrm{ng} \mathrm{m}^{-3}$, average $555 \mathrm{ng} \mathrm{m}^{-3}$ ), hydroxyacetone $\left(0-707 \mathrm{ng} \mathrm{m}^{-3}, 163 \mathrm{ng} \mathrm{m}^{-3}\right.$ ), and glyoxal (198-1396 $\mathrm{ng} \mathrm{m}^{-3}, 720 \mathrm{ng} \mathrm{m}^{-3}$ ) were among the highest ever reported in the urban and forest atmosphere, and were more than 10 times more abundant than particulate carbonyls.

\subsection{BC measurement comparisons and $\Delta \mathrm{BC}$ / $\Delta \mathrm{CO}$ ra- tio analysis}

In addition to the year-round observations of $\mathrm{BC}$ using a multi-angle absorption photometer (MAAP, model 5012, Thermo Scientific, Waltham, MA, USA) instrument at the 
summit of Mt. Tai, we installed several more instruments, namely a particle soot absorption photometer (PSAP; Radiance Research, Shoreline, WA, USA) and an ECOC (elemental carbon-organic carbon) semi-continuous analyzer (Sunset Laboratory, Tigard, OR, USA), operated either with IMPROVE-like or NIOSH temperature programs, for the purpose of instrument inter-comparison during the campaign period (Kanaya et al., 2008). These instruments were operated either with $\mathrm{PM}_{1}$ or $\mathrm{PM}_{2.5}$ cyclones, depending on the time period. An aethalometer (AE-21, Magee Scientific, Berkeley, CA, USA) was also operated for several days during the first part of the campaign.

The regression analysis for each pair showed that the correlations were strong, and the slopes ranged from 1.03 to 1.54 for the first period (before 20 June), with $\mathrm{PM}_{1}$ sampling, and from 1.07 to 1.46 for the second period (after 20 June), using the IMPROVE-like temperature program for EC analysis with $\mathrm{PM}_{2.5}$ sampling (see Fig. 8 of Kanaya et al., 2008). Considering that disagreement up to a factor of 4 (e.g., Jeong et al., 2004) was reported in the United States among similar instruments, the spread at Mt. Tai was thought to be relatively narrow. They therefore obtained $\mathrm{BC}$ concentration data suitable for constraining $\mathrm{BC}$ emission rates from China, whose uncertainty was thought to be large (e.g., factors of 4-5; Bond et al., 2004; Streets et al., 2003).

They also found that enhanced MAAP_BC/EC ratios (e.g., higher than 2) occurred only when low $\mathrm{NO}_{\mathrm{x}} / \mathrm{NO}_{\mathrm{y}}$ ratios were recorded, implying that aging is related to large MAAP_BC/EC ratios. Given that the tendency to underestimate $\mathrm{EC}$ is not straightforwardly explained in terms of aging, it is reasonable to conclude that the $\mathrm{BC}$ particles are coated by transparent materials after aging and that the MAAP results based on absorbance measurements gave overestimates, possibly as a result of a lens effect induced by the coating.

Pan et al. (2013) studied $\triangle B C / \triangle C O$ ratios in detail, using $\mathrm{CO}$ as a conservative tracer, during the biomass-burning events and found that the ratio had a clear tendency to decrease with increasing transport time of the air mass from the biomass-burning source area. Here, the transport time was estimated using the WRF-FLEXPART model. The estimated lifetime of BC was ca. 4.1 days, near the lower limit of the range suggested by past studies.

\subsection{PM and inorganic ion/element concentrations}

The daily mass concentrations of TSP and $\mathrm{PM}_{2.5}$, and their ionic and element compositions, were measured during MTX2006 and compared with the data obtained in spring (from March to early May) 2006 and 2007 at the same site (Deng et al., 2011). The concentrations of TSP and $\mathrm{PM}_{2.5}$, determined using the filter-weighing method, ranged from 49 to $277 \mu \mathrm{g} \mathrm{m}^{-3}$ and from 48 to $236 \mu \mathrm{g} \mathrm{m}^{-3}$, respectively, during MTX2006. The average $\mathrm{PM}_{2.5}$ / TSP ratio was 0.37 in spring and 0.91 in summer in 2006, indicating that fine particles dominated in summer, whereas coarse particles dom-

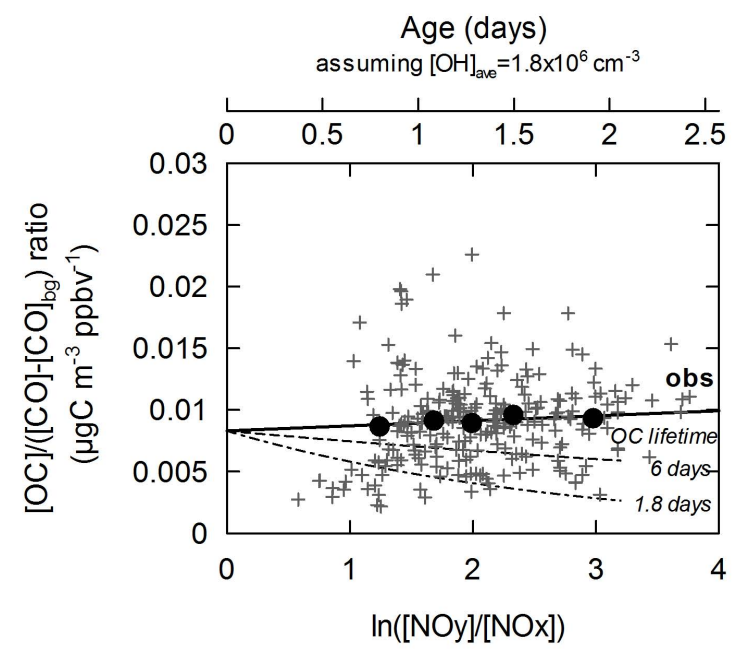

Fig. 11. $\Delta[\mathrm{OC}] / \Delta[\mathrm{CO}]$ ratio during the latter period of the campaign (from 16 June 2006), without influence from biomass burning, plotted against $\ln \left(\left[\mathrm{NO}_{\mathrm{y}}\right] /\left[\mathrm{NO}_{\mathrm{x}}\right]\right.$ ) (lower $x$ axis) and the converted air mass age (upper $x$ axis), calculated with the average $\mathrm{OH}$ concentrations during this period. The $\mathrm{CO}$ background concentration, $[\mathrm{CO}]_{\mathrm{bg}}$, was assumed to be $90 \mathrm{ppbv}$. Dashed line and dasheddotted line represent the theoretical decays with assumed OC lifetimes of 6 and 1.8 days, respectively.

inated in spring. This ratio in summer is much higher than those in other cities in China (0.27-0.68), indicating that the air mass at Mt. Tai is chemically very aged, consistent with other evidence discussed earlier.

Water-soluble ions contributed $10.8 \%$ of TSP and $24.0 \%$ of $\mathrm{PM}_{2.5}$ by mass in spring, compared with 40.9 and $41.1 \%$ during MTX2006 (Deng et al., 2011). Sulfate, nitrate, and ammonium ions were the major water-soluble species in $\mathrm{PM}_{2.5}$, accounting for 61.5 and $72.7 \%$ of the total measured ions in spring and during MTX2006, respectively. Also, higher concentrations of $\mathrm{K}^{+}$, a tracer of biomass-burning sources, were observed during MTX2006, accounting for $8.3 \%$ of the total ions in TSP, with high correlations with $\mathrm{BC}(R=0.90)$ and oxalic acid $(R=0.87)$.

$\mathrm{Xu}$ et al. (2009) reported size-segregated water-soluble ions and metals in aerosol particles. Sulfate, ammonium, and $\mathrm{K}$ ions, and $\mathrm{Pb}, \mathrm{Zn}$, and Ti peaked in the accumulation mode $(0.43-1.1 \mu \mathrm{m})$. $\mathrm{Ca}, \mathrm{Mg}, \mathrm{Fe}, \mathrm{Al}, \mathrm{Ba}$, and $\mathrm{Mn}$ had peaks in the coarse mode $(4.7-5.8 \mu \mathrm{m})$. In contrast, nitrate, $\mathrm{Na}$, and $\mathrm{Cl}$ ions, and $\mathrm{Co}, \mathrm{Ni}, \mathrm{Mo}$, and $\mathrm{Cu}$ showed bimodal distributions $(0.43-0.65$ and $4.7-5.8 \mu \mathrm{m})$.

\subsection{Organic aerosols: photochemical formation and molecular composition}

Figure 11 shows the dependence of the $\Delta[\mathrm{OC}] / \Delta[\mathrm{CO}]$ ratio on the $\ln \left(\left[\mathrm{NO}_{\mathrm{y}}\right] /\left[\mathrm{NO}_{\mathrm{x}}\right]\right)$ value, as an index of air mass age, during the latter period of the campaign (from 16 June 2006), with negligible influence from biomass burning. Here 
$\mathrm{CO}$ is considered to be a relatively inert chemical species and its background concentration $\left([\mathrm{CO}]_{\mathrm{bg}}\right.$ ) was assumed to be $90 \mathrm{ppbv}$. The $\Delta[\mathrm{OC}] / \Delta[\mathrm{CO}]$ ratio is almost unchanged with photochemical aging, and shows a trend clearly different from a decay with a lifetime of $\sim 6$ days assumed for primary organic matters in chemistry-climate models (IPCC, 2007), or a decay with an even shorter time constant of $\sim 1.8$ days, suggested from the analysis for the air masses influenced by biomass burning during the first-half period of MTX2006 (Pan et al., 2013). This clearly suggests that carbon mass flux from gas-to-particle conversion is present for the studied timescale. Robinson et al. (2007) assumed that SVOC and IVOC (semi-volatile and intermediate volatility organic compound) vapors are oxidized via a gas-phase $\mathrm{OH}$ reaction with a rate constant of $4 \times 10^{-11} \mathrm{~cm}^{3}$ molecule $\mathrm{e}^{-1} \mathrm{~s}^{-1}$, to yield next-generation compounds that are 10 times less volatile, and calculated larger partitioning from gas-to-particle phases. The assumed reaction rate is about four times faster than the oxidation of $\mathrm{NO}_{\mathrm{x}}$ to $\mathrm{NO}_{\mathrm{y}}$. To cover eight generations, corresponding to the eight orders of magnitude range in volatility considered in their model study, a $\ln \left(\left[\mathrm{NO}_{\mathrm{y}}\right] /\left[\mathrm{NO}_{\mathrm{x}}\right]\right)$ range between 0 and 2 needs to be studied. The study at Mt. Tai actually covered this range and the data are suitable for the quantitative investigation of possible increases in $\mathrm{OC}$ with photochemical aging.

Fu et al. (2008) summarized the organic molecular compositions (except dicarboxylic acids) of TSP samples collected on quartz filters using a high-volume air sampler, and analyzed their temporal variations. They found that $n$ alkanes, fatty acids, fatty alcohols, sugars, glycerol, polyacids, and phthalate esters are the major species, and that lignin and resin products, sterols, aromatic acids, hopanes, and polycyclic aromatic hydrocarbons (PAHs), are minor species. They showed the importance of plant emissions of waxes and soil resuspension, as well as biomass burning, as source processes. From the same TSP samples, Kawamura et al. (2013b) reported that the water-soluble OC (WSOC)/total carbon (TC) ratio was $0.41 \pm 0.09$ in average, which is larger than 0.35 or less observed for $\mathrm{PM}_{2.5}$ samples at Changping or other Chinese cities such as Shanghai, Lanzhou, and Guangzhou (Pathak et al., 2011). Kawamura et al. (2013b) also reported that very high concentrations of saturated and unsaturated diacids $\left(\mathrm{C}_{2}-\mathrm{C}_{11}\right.$, up to $6.1 \mu \mathrm{g} \mathrm{m}^{-3}$ ) were detected among WSOC (ranged from 1 to $37 \mu \mathrm{g} \mathrm{m}^{-3}$ ), with a predominance of oxalic $\left(\mathrm{C}_{2}\right)$ acid followed by malonic $\left(\mathrm{C}_{3}\right)$ and succinic $\left(\mathrm{C}_{4}\right)$ acids, as well as $\mathrm{C}_{2}-\mathrm{C}_{9} \omega$-oxocarboxylic acids, pyruvic acid, and $\alpha$ dicarbonyls (glyoxal and methylglyoxal). The highest concentrations of total diacids $\left(>6 \mu \mathrm{g} \mathrm{m}^{-3}\right)$ found at Mt. Tai were several times higher than those reported at ground levels in Chinese megacities. The temporal variations in diacids were interpreted to be caused by a combination of direct emissions from field burning of agricultural wastes, and secondary photochemical production, via oxidation of volatile and semi-volatile organic precursors emitted from

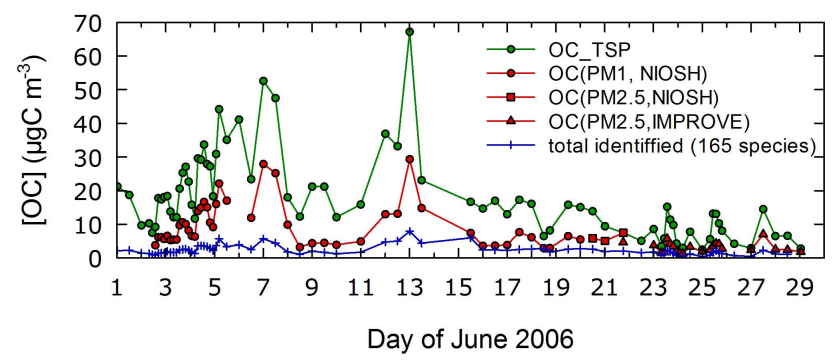

Fig. 12. Time series of OC concentrations measured for TSP filter samples (green) and size-segregated $\mathrm{OC}$ concentrations $\left(\mathrm{PM}_{1}\right.$ and $\mathrm{PM}_{2.5}$ ) measured using a semi-continuous ECOC analyzer (red). The sum of molecularly identified OCs (165 species) for TSP samples is shown in blue. The time intervals of the TSP samplings are used in all cases.

field burning of wheat straw, during transport to the summit of the mountain. Fu et al. (2010) quantified the oxidation products from isoprene (e.g., 2-methylerythritol), $\alpha / \beta$ pinene (e.g., 3-hydroxyglutaric acid), and $\beta$-caryophyllene (e.g., $\beta$-caryophyllinic acid) in the filter samples and suggested the importance of isoprene-derived secondary organic carbons. Fu et al. (2012) studied the diurnal variations in 12 organic compound classes consisting of more than 130 species, and their stable isotopic compositions. During the biomass-burning period in early June, the diurnal trends of most of the primary and secondary organic aerosol tracers were characterized by concentration peaks observed at midnight or in the early morning, similar to BC peaks in the early morning (Fig. 6), whereas in late June (without the influence of intense biomass burning) most of the organic species peaked in the late afternoon. A strong anticorrelation was found between levoglucosan and $\delta^{13} \mathrm{C}$ values, again suggesting the importance of crop residue burning (Fig. 9). Altogether, 165 molecularly identified organic compounds, including diacids, oxo/ketocarboxylic acids, dicarbonyls, $n$-alkanes, fatty acids, fatty alcohols, sugars, phthalates, polyols, polyacids, aromatic acids, lignin and resin products, sterols, hopanes, PAHs, and biogenic secondary organic aerosol tracers (Fu et al., 2012; Kawamura et al., $2013 \mathrm{~b}$ ) accounted for $14 \pm 6 \%$ of the total OC mass in the TSP. The OC mass concentrations in the TSP were $2.6 \pm 0.8$ times larger than those in $\mathrm{PM}_{1}$ (before 20 June, using the NIOSH protocol, $n=46$ ) and $2.4 \pm 0.7$ times larger than those in $\mathrm{PM}_{2.5}$ (after 20 June, IMPROVE-like protocol, $n=22$ ) analyzed using a semi-continuous ECOC analyzer (Fig. 12). This suggests the presence of coarse organic aerosol particles, and the presence of molecularly unidentified organics, even in $\mathrm{PM}_{1}$.

Wang et al. (2009) investigated the size distributions of $n$-alkanes, PAHs, and hopanes collected using an Andersen eight-stage air sampler during the period 22-29 June 2006. The size distributions were compared with those sampled in winter at the summit of Mt. Tai and those sampled 
in the marine boundary layer and urban atmosphere. During MTX2006, bimodal distributions with peak sizes of 0.71.1 and 4.7-5.8 $\mu \mathrm{m}$ were recorded for both plant-wax and anthropogenic $n$-alkanes. All the PAHs had maximums in the range $0.7-1.1 \mu \mathrm{m}$. Hopanes showed bimodal distributions with peaks in the ranges of $0.7-1.1 \mu \mathrm{m}$ and $>3.3 \mu \mathrm{m}$.

\section{Summary}

MTX2006 was the first field campaign performed at a site geographically representing regional air pollution over the NCP. Comprehensive measurements and model simulations of $\mathrm{O}_{3}$ and its precursors, and aerosol chemical species were performed. The period of the study (June) was chosen to target high $\mathrm{O}_{3}$ concentrations (monthly average $82 \mathrm{ppbv}$ ). Together with high $\mathrm{O}_{3}$ levels, we found very high concentrations of organic aerosols, probably as a result of extensive photochemistry. We found that OCRB after the harvesting of winter wheat was one of the most important factors leading to these high concentrations, and this was supported by coincident observations of peak concentrations of biomass-burning tracers such as levoglucosan, $\mathrm{K}^{+}, \mathrm{CH}_{3} \mathrm{Cl}$, and $\mathrm{CH}_{3} \mathrm{CN}$, and by low $\delta^{13} \mathrm{C}$ values of organic aerosols. A large fraction of high $\mathrm{O}_{3}$ was photochemically produced in CEC, generally under $\mathrm{NO}_{\mathrm{x}}$-limited conditions, with some slowing effects as a result of $\mathrm{O}_{3}$-aerosol interactions through $J$ value reduction and heterogeneous chemistry. The validation of satellitebased observations of tropospheric $\mathrm{NO}_{2}$ VCDs was performed using MAX-DOAS observations. Instrument intercomparisons were made for $\mathrm{BC}$ measurements, which provided better constraints for $\mathrm{BC}$ emission rates from this region. Strong positive RF by $\mathrm{BC}$ was implied. The $\mathrm{BC}$ lifetime in the atmosphere was estimated using the transport time from biomass-burning source areas. The inorganic and organic compositions of aerosol particles were studied in detail. Molecularly identified organic compounds accounted for $14 \%$ of total OC in the TSP.

Acknowledgements. Support from local staff at the observatory is gratefully acknowledged. This work was supported by the Global Environment Research Fund and by the Environmental Research and Technology Development Fund (S-7, C-081, B-051) of the Ministry of the Environment, Japan.

Edited by: S. C. Liu

\section{References}

Akimoto, H.: Global Air Quality and Pollution, Science, 302, 17161719, 2003.

Barletta, B., Meinardi, S., Rowland, F. S., Chan, C. Y., Wang, X., Zou, S., Chan, L. Y., and Blake, D. R.: Volatile organic compounds in 43 Chinese cities, Atmos. Environ., 32, 5979-5990, 2005.
Beirle, S., Platt, U., Wenig, M., and Wagner, T.: Highly resolved global distribution of tropospheric $\mathrm{NO}_{2}$ using GOME narrow swath mode data, Atmos. Chem. Phys., 4, 1913-1924, 2004, http://www.atmos-chem-phys.net/4/1913/2004/.

Bond, T. C., Streets, D. G., Yarber, K. F., Nelson, S. M., Woo, J.-H., and Klimont, Z.: A technology-based global inventory of black and organic carbon emissions from combustion, J. Geophys. Res., 109, D14203, doi:10.1029/2003JD003697, 2004.

Bond, T. C., Zarzycki, C., Flanner, M. G., and Koch, D. M.: Quantifying immediate radiative forcing by black carbon and organic matter with the Specific Forcing Pulse, Atmos. Chem. Phys., 11, 1505-1525, doi:10.5194/acp-11-1505-2011, 2011.

Byun, D. W. and Ching, J. K. S. (Eds.): Science algorithms of the EPA Models-3 community multiscale air quality (CMAQ) modeling system, EPA/600/R-99/030, USEPA NERL, Research Triangle Park, USA, 1999.

Chin, M., Chu, A., Levy, R., Remer, L., Kaufman, Y., Holben, B., Eck. T., Ginoux, P., and Gao, Q. X.: Aerosol distribution in the Northern Hemisphere during ACE-Asia: Results from global model, satellite observations, and Sun photometer Measurements, J. Geophys. Res., 109, D23S90, doi:10.1029/2004JD004829, 2004.

Deng, C., Zhuang, G., Huang, K., Li, J., Zhang, R., Wang, Q., Liu, T., Sun, Y., Guo, Z., Fu, J. S., and Wang, Z.: Chemical characterization of aerosols at the summit of Mountain Tai in Central East China, Atmos. Chem. Phys., 11, 7319-7332, doi:10.5194/acp11-7319-2011, 2011.

Ding, A. J., Wang, T., Thouret, V., Cammas, J.-P., and Nédélec, P.: Tropospheric ozone climatology over Beijing: analysis of aircraft data from the MOZAIC program, Atmos. Chem. Phys., 8, 1-13, doi:10.5194/acp-8-1-2008, 2008.

Fu, P. Q., Kawamura, K., Okuzawa, K., Aggarwal, S. G., Wang, G. H., Kanaya, Y., and Wang, Z. F.: Organic molecular compositions and temporal variations of summertime mountain aerosols over Mt. Tai, North China Plain, J. Geophys. Res.-Atmos., 113, D19107, doi:10.1029/2008JD009900, 2008.

Fu, P. Q., Kawamura, K., Kanaya, Y., and Wang, Z. F.: Contributions of biogenic volatile organic compounds to the formation of secondary organic aerosols over Mt. Tai, Central East China, Atmos. Environ., 44, 4817-4826, 2010.

Fu, P. Q., Kawamura, K., Chen, J., Li, J., Sun, Y. L., Liu, Y., Tachibana, E., Aggarwal, S. G., Okuzawa, K., Tanimoto, H., Kanaya, Y., and Wang, Z. F.: Diurnal variations of organic molecular tracers and stable carbon isotopic composition in atmospheric aerosols over Mt. Tai in the North China Plain: an influence of biomass burning, Atmos. Chem. Phys., 12, 8359-8375, doi:10.5194/acp-12-8359-2012, 2012.

Fuhrer, J., Skarby, L., and Ashmore, M.: Critical levels of ozone effect in Europe, Environ. Pollut., 97, 91-106, 1997.

Gao, J., Wang, T., Ding, A. J., and Liu, C. B.: Observational study of ozone and carbon monoxide at the summit of mount Tai $(1534 \mathrm{~m}$ a.s.1.) in central-eastern China, Atmos. Environ., 39, 4779-4791, 2005.

Ge, B. Z., Wang, Z. F., Xu, X. B., Tang, J., He, Y. J., Uno, I., and Ohara, T.: Impact of the East Asian summer monsoon on longterm variations in the acidity of summer precipitation in Central China, Atmos. Chem. Phys., 11, 1671-1684, doi:10.5194/acp11-1671-2011, 2011. 
He, Y. J., Uno, I., Wang, Z. F., Pochanart, P., Li, J., and Akimoto, H.: Significant impact of the East Asia monsoon on ozone seasonal behavior in the boundary layer of Eastern China and the west Pacific region, Atmos. Chem. Phys., 8, 7543-7555, doi:10.5194/acp-8-7543-2008, 2008.

Inomata, S., Tanimoto, H., Kameyama, S., Tsunogai, U., Irie, H., Kanaya, Y., and Wang, Z.: Technical Note: Determination of formaldehyde mixing ratios in air with PTR-MS: laboratory experiments and field measurements, Atmos. Chem. Phys., 8, 273284, doi:10.5194/acp-8-273-2008, 2008.

Inomata, S., Tanimoto, H., Kato, S., Suthawaree, J., Kanaya, Y., Pochanart, P., Liu, Y., and Wang, Z.: PTR-MS measurements of non-methane volatile organic compounds during an intensive field campaign at the summit of Mount Tai, China, in June 2006, Atmos. Chem. Phys., 10, 7085-7099, doi:10.5194/acp-10-70852010, 2010.

IPCC Working Group I, Climate Change 2007, The Physical Science Basis, Cambridge University Press, 2007.

Irie, H., Kanaya, Y., Akimoto, H., Tanimoto, H., Wang, Z., Gleason, J. F., and Bucsela, E. J.: Validation of OMI tropospheric $\mathrm{NO}_{2}$ column data using MAX-DOAS measurements deep inside the North China Plain in June 2006: Mount Tai Experiment 2006, Atmos. Chem. Phys., 8, 6577-6586, doi:10.5194/acp-8-6577-2008, 2008.

Jeong, C.-H., Hopke, P. K., Kim, E., and Lee, D.-W.: The comparison between thermal-optical transmittance elemental carbon and Aethalometer black carbon measured at multiple monitoring sites, Atmos. Environ., 38, 5193-5204, 2004.

Kanaya, Y., Komazaki, Y., Pochanart, P., Liu, Y., Akimoto, H., Gao, J., Wang, T., and Wang, Z.: Mass concentrations of black carbon measured by four instruments in the middle of Central East China in June 2006, Atmos. Chem. Phys., 8, 7637-7649, doi:10.5194/acp-8-7637-2008, 2008.

Kanaya, Y., Pochanart, P., Liu, Y., Li, J., Tanimoto, H., Kato, S., Suthawaree, J., Inomata, S., Taketani, F., Okuzawa, K., Kawamura, K., Akimoto, H., and Wang, Z. F.: Rates and regimes of photochemical ozone production over Central East China in June 2006: a box model analysis using comprehensive measurements of ozone precursors, Atmos. Chem. Phys., 9, 7711-7723, doi:10.5194/acp-9-7711-2009, 2009.

Karl, T. G., Christian, T. J., Yokelson, R. J., Artaxo, P., Hao, W. M., and Guenther, A.: The Tropical Forest and Fire Emissions Experiment: method evaluation of volatile organic compound emissions measured by PTR-MS, FTIR, and GC from tropical biomass burning, Atmos. Chem. Phys., 7, 5883-5897, doi:10.5194/acp-7-5883-2007, 2007.

Kawamura, K., Okuzawa, K., Aggarwal, S. G., Irie, H., Kanaya, Y., and Wang, Z.: Determination of gaseous and particulate carbonyls (glycolaldehyde, hydroxyacetone, glyoxal, methylglyoxal, nonanal and decanal) in the atmosphere at Mt. Tai, Atmos. Chem. Phys., 13, 5369-5380, doi:10.5194/acp-13-53692013, 2013a.

Kawamura, K., Tachibana, E., Okuzawa, K., Aggarwal, S. G., Kanaya, Y., and Wang, Z. F.: High abundances of water-soluble dicarboxylic acids, ketocarboxylic acids and $\alpha$-dicarbonyls in the mountaintop aerosols over the North China Plain during wheat burning season, Atmos. Chem. Phys., 13, 8285-8302, doi:10.5194/acp-13-8285-2013, 2013 b.
Kleinman, L. I., Daum, P. H., Imre, D., Lee, Y.-N., Nunnermacker, L. J., Springston, S. R., Weinstein-Lloyd, J., and Rudolph, J.: Ozone production rate and hydrocarbon reactivity in 5 urban areas: A cause of high ozone concentration in Houston, Geophys. Res. Lett., 29, 1467, doi:10.1029/2001GL014569, 2002.

Kleinman, L. I., Springston, S. R., Daum, P. H., Lee, Y.-N., Nunnermacker, L. J., Senum, G. I., Wang, J., Weinstein-Lloyd, J., Alexander, M. L., Hubbe, J., Ortega, J., Canagaratna, M. R., and Jayne, J.: The time evolution of aerosol composition over the Mexico City plateau, Atmos. Chem. Phys., 8, 1559-1575, doi:10.5194/acp-8-1559-2008, 2008.

Li, J., Wang, Z. F., Akimoto, H., Gao, C., Pochanart, P., and Wang, X.: Modeling study of ozone seasonal cycle in lower troposphere over east Asia, J. Geophys. Res., 112, D22S25, doi:10.1029/2006JD008209, 2007.

Li, J., Wang, Z., Akimoto, H., Yamaji, K., Takigawa, M., Pochanart, P., Liu, Y., Tanimoto, H., and Kanaya, Y.: Nearground ozone source attributions and outflow in central eastern China during MTX2006, Atmos. Chem. Phys., 8, 7335-7351, doi:10.5194/acp-8-7335-2008, 2008a.

Li, J., Pochanart, P., Wang, Z., Liu, Y., Yamaji, K., Takigawa, M., Kanaya, Y., and Akimoto, H.: Impact of chemical production and transport on summertime diurnal ozone behavior at a mountainous site in North China Plain, SOLA, 4, 121-124, 2008 b.

Li, J., Wang, Z., Yamaji, K., Takigawa, M., Kanaya, Y., Pochanart, P., Liu, Y., Irie, H., Hu, B., Tanimoto, H., and Akimoto, H.: Impact of aerosols on summertime tropospheric photolysis frequencies and photochemistry over Central Eastern China, Atmos. Environ., 45, 1817-1829, 2011.

Lin, P., Hu, M., Deng, Z., Slanina, J., Han, S., Kondo, Y., Takegawa, N., Miyazaki, Y., Zhao, Y., and Sugimoto, N.: Seasonal and diurnal variations of organic carbon in PM2.5 in Beijing and the estimation of secondary organic carbon, J. Geophys. Res., 114, D00G11, doi:10.1029/2008JD010902, 2009.

Lin, W., Xu, X., Zhang, X., and Tang, J.: Contributions of pollutants from North China Plain to surface ozone at the Shangdianzi GAW station, Atmos. Chem. Phys., 8, 5889-5898, 2008, http://www.atmos-chem-phys.net/8/5889/2008/.

Liu, Y., Shao, M., Kuster, W. C., Goldan, P. D., Li, X., Lu, S., and de Gouw, J. A.: Source identification of reactive hydrocarbons and oxygenated VOCs in the summertime in Beijing, Environ. Sci. Technol., 43, 75-81, 2009.

Luo, C., St. John, J. C., Xiuji, Z., Lam, K. S., Wang, T., and Chameides, W. L.: A nonurban ozone air pollution episode over eastern China: Observations and model simulations, J. Geophys. Res., 105, 1889-1908, doi:10.1029/1999JD900970, 2000.

Mao, J., Fan, S., Jacob, D. J., and Travis, K. R.: Radical loss in the atmosphere from $\mathrm{Cu}-\mathrm{Fe}$ redox coupling in aerosols, Atmos. Chem. Phys., 13, 509-519, doi:10.5194/acp-13-509-2013, 2013.

Martin, R. V., Sioris, C. E., Chance, K., Ryerson, T. B, Timothy Bertram, H., Wooldridge, P. J., Cohen, R. C., Neuman, J. A., Swanson, A., and Flocke, F. M.: Evaluation of space-based constraints on global nitrogen oxide emissions with regional aircraft measurements over and downwind of eastern North America, J. Geophys. Res., 111, D15308, doi:10.1029/2005JD006680, 2006.

Ohara, T., Akimoto, H., Kurokawa, J., Horii, N., Yamaji, K., Yan, X., and Hayasaka, T.: An Asian emission inventory of anthropogenic emission sources for the period 1980-2020, Atmos. Chem. Phys., 7, 4419-4444, doi:10.5194/acp-7-4419-2007, 
2007.

Pan, X. L., Kanaya, Y., Wang, Z. F., Komazaki, Y., Taketani, F., Akimoto, H., Pochanart, P., and Liu, Y.: Estimation of lifetime of carbonaceous aerosol from open crop residue burning during Mount Tai Experiment 2006 (MTX2006), Atmos. Chem. Phys. Discuss., 12, 14363-14392, doi:10.5194/acpd-12-14363-2012, 2012.

Pan, X., Kanaya, Y., Wang, Z.. Komazaki, Y., Taketani, F., Akimoto, H., and Pochanart, P.: Variation of carbonaceous aerosols from open crop residue burning with transport and its implication to estimate their lifetimes, Atmos. Environ., 74, 301-310, 2013.

Parrish, D. D.: Critical evaluation of US on-road vehicle emission inventories, Atmos. Environ., 40, 2288-2300, 2006.

Parrish, D. D., Trainer, M., Hereid, D., Williams, E. J., Olszyna, K. J., Harley, R. A., Meagher, J. F., and Fehsenfeld, F. C.: Decadal change in carbon monoxide to nitrogen oxide ratio in U.S. vehicular emissions, J. Geophys. Res., 107, ACH 5-1-ACH 5-9, doi:10.1029/2001JD000720, 2002.

Pathak, R. K., Wang, T., Ho, K. F., and Lee, S. C.: Characteristics of summertime $\mathrm{PM}_{2.5}$ organic and elemental carbon in four major Chinese cities: Implications of high acidity for water-soluble organic carbon (WSOC), Atmos. Environ., 45, 318-325, 2011.

Richter, A. Burrows, J. P., Nuss, H., Granier C., and Niemeier, U.: Increase in tropospheric nitrogen dioxide over China observed from space, Nature, 437, 129-132, doi:10.1038/nature04092, 2005.

Robinson, A. L., Donahue, N. M., Shrivastava, M. K., Weitkamp, E. A., Sage, A. M., Grieshop, A. P., Lane T. E., Pandis, S. N., and Pierce, J. R.: Rethinking organic aerosols: Semivolatile emissions and photochemical aging, Science, 315, 1259-1262, 2007.

Shao, M., Lu, S., Liu, Y., Xie, X., Chang, C., Huang, S., and Chen, Z.: Volatile organic compounds measured in summer in Beijing and their role in ground level ozone formation, J. Geophys. Res., 114, D00G06, doi:10.1029/2008JD010863, 2009.

Streets, D. G., Bond, T. C., Carmichael, G. R., Fernandes, S. D., Fu, Q., He, D., Klimont, Z., Elson, S. M., Tsai, N. Y., Wang, M. Q., Woo, J. H., and Yarber, K. F.: An inventory of gaseous and primary aerosol emissions in Asia in the year 2000, J. Geophys. Res., 108, 8809, doi:10.1029/2002JD003093, 2003.

Suthawaree, J., Kato, S., Okuzawa, K., Kanaya, Y., Pochanart, P., Akimoto, H., Wang, Z., and Kajii, Y.: Measurements of volatile organic compounds in the middle of Central East China during Mount Tai Experiment 2006 (MTX2006): observation of regional background and impact of biomass burning, Atmos. Chem. Phys., 10, 1269-1285, doi:10.5194/acp-10-1269-2010, 2010.

Taketani, F., Kanaya, Y., Pochanart, P., Liu, Y., Li, J., Okuzawa, K., Kawamura, K., Wang, Z., and Akimoto, H.: Measurement of overall uptake coefficients for $\mathrm{HO}_{2}$ radicals by aerosol particles sampled from ambient air at Mts. Tai and Mang (China), Atmos. Chem. Phys., 12, 11907-11916, doi:10.5194/acp-1211907-2012, 2012.

Tang, J. H., Chan, L. Y., Chan, C. Y., Li, Y. S., Chang, C. C., Liu, S. C., Wu, D., and Li, Y. D.: Characteristics and diurnal variations of NMHCs at urban, suburban, and rural sites in the Pearl River Delta and a remote site in South China, Atmos. Environ., 41, 8620-8632, 2007.

USEPA: Air Quality Criteria for Ozone and Related Photochemical Oxidants (final), EPA/600/R-05/004aF-cF, US Environmental Protection Agency, Washington, DC, 2006.
Wang, G., Kawamura, K., Xie, M., Hu, S., Gao, S., Cao, J., An, Z., and Wang, Z.: Size-distributions of n-alkanes, PAHs and hopanes and their sources in the urban, mountain and marine atmospheres over East Asia, Atmos. Chem. Phys., 9, 8869-8882, doi:10.5194/acp-9-8869-2009, 2009.

Wang, T., Cheung, V. T. F., Anson, M., and Li, Y. S.: Ozone and related gaseous pollutants in the boundary layer of eastern China: Overview of the recent measurements at a rural site, Geophys. Res. Lett., 28, 2373-2376, doi:10.1029/2000GL012378, 2001.

Wang, T., Cheung, T. F., Li, Y. S., Yu, X. M., and Blake, D. R.: Emission characteristics of $\mathrm{CO}, \mathrm{NOx}, \mathrm{SO}_{2}$ and indications of biomass burning observed at a rural site in eastern China, J. Geophys. Res., 107, 4157, doi:10.1029/2001JD000724, 2002.

Wang, T., Wong, C. H., Cheung, T. F., Blake, D. R., Arimoto, R., Baumann, K., Tang, J., Ding, G. A., Yu, X. M., Li, Y. S., Streets, D. G., and Simpson, I. J.: Relationships of trace gases and aerosols and the emission characteristics at Lin'an, a rural site in eastern China, during spring 2001, J. Geophys. Res., 109, D19S05, doi:10.1029/2003JD004119, 2004.

Wang, T., Ding, A., Gao, J., and Wu, W. S.: Strong ozone production in urban plumes from Beijing, China, Geophys. Res. Lett., 33, L21806, doi:10.1029/2006GL027689, 2006.

Wang, Y., McElroy, M. B., Munger, J. W., Hao, J., Ma, H., Nielsen, C. P., and Chen, Y.: Variations of $\mathrm{O}_{3}$ and $\mathrm{CO}$ in summertime at a rural site near Beijing, Atmos. Chem. Phys., 8, 6355-6363, doi:10.5194/acp-8-6355-2008, 2008a.

Wang, Y., Wai, K. M., Gao, J., Liu, X. H., Wang T., and Wang, W. $\mathrm{X}$.: The impacts of anthropogenic emissions on the precipitation chemistry at an elevated site in North-eastern China, Atmos. Environ., 42, 2959-2970, 2008b.

Wang, Z. F. Li, J., Wang, X. Q, Pochanart, P., and Akimoto, H.: Modeling of Regional High Ozone Episode Observed at Two Mountain Sites (Mt. Tai and Huang) in East China, J. Atmos. Chem., 55, 253-272, 2006.

WHO: Health Aspects of Air Pollution with Particulate Matter, Ozone and Nitrogen Dioxide, 98 pp., World Health Organization, Bonn, Germany, 2003.

Wood, E. C., Herndon, S. C., Onasch, T. B., Kroll, J. H., Canagaratna, M. R., Kolb, C. E., Worsnop, D. R., Neuman, J. A., Seila, R., Zavala, M., and Knighton, W. B.: A case study of ozone production, nitrogen oxides, and the radical budget in Mexico City, Atmos. Chem. Phys., 9, 2499-2516, doi:10.5194/acp-9-24992009, 2009.

Xu, X., Lin, W., Wang, T., Yan, P., Tang, J., Meng, Z., and Wang, Y.: Long-term trend of surface ozone at a regional background station in eastern China 1991-2006: enhanced variability, Atmos. Chem. Phys., 8, 2595-2607, doi:10.5194/acp-8-2595-2008, 2008.

Xu, H., Wang, Y., Wen, T., Yang, Y., and Zhao, Y.: Characteristics and source apportionment of atmospheric aerosols at the summit of Mount Tai during summertime, Atmos. Chem. Phys. Discuss., 9, 16361-16379, doi:10.5194/acpd-9-16361-2009, 2009.

Yamaji, K., Li, J., Uno, I., Kanaya, Y., Irie, H., Takigawa, M., Komazaki, Y., Pochanart, P., Liu, Y., Tanimoto, H., Ohara, T., Yan, X., Wang, Z., and Akimoto, H.: Impact of open crop residual burning on air quality over Central Eastern China during the Mount Tai Experiment 2006 (MTX2006), Atmos. Chem. Phys., 10, 7353-7368, doi:10.5194/acp-10-7353-2010, 2010. 
Yan, P., Tang, J., Huang, J., Mao, J. T., Zhou, X. J., Liu, Q., Wang, Z. F., and Zhou, H. G.: The measurement of aerosol optical properties at a rural site in Northern China, Atmos. Chem. Phys., 8, 2229-2242, doi:10.5194/acp-8-2229-2008, 2008.

Yan, P., Zhang, R., Huan, N., Zhou, X., Zhang, Y., Zhou, H., and Zhang, L.: Characteristics of aerosols and mass closure study at two WMO GAW regional background stations in eastern China, Atmos. Environ., 60, 121-131, 2012.
Yang, M., Howell, S. G., Zhuang, J., and Huebert, B. J.: Attribution of aerosol light absorption to black carbon, brown carbon, and dust in China - interpretations of atmospheric measurements during EAST-AIRE, Atmos. Chem. Phys., 9, 2035-2050, doi:10.5194/acp-9-2035-2009, 2009. 